\title{
Chemical composition of modern and fossil hippopotamid teeth and implications for paleoenvironmental reconstructions and enamel formation - Part 2: Alkaline earth elements as tracers of watershed hydrochemistry and provenance
}

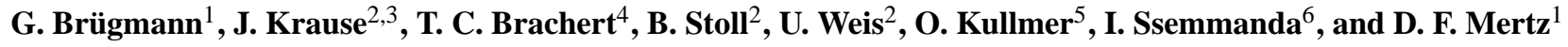 \\ ${ }^{1}$ Institut für Geowissenschaften, Johannes Gutenberg-Universität Mainz, Joh.-Joachim-Becher-Weg 21, 55099 Mainz, \\ Germany \\ ${ }^{2}$ Max-Planck-Institut für Chemie, Joh.-Joachim-Becher-Weg 27, 55128 Mainz, Germany \\ ${ }^{3}$ Institut für Mineralogie, Corrensstraße 24, Universität Münster, D48149 Münster, Germany \\ ${ }^{4}$ Institut für Geophysik und Geologie, Talstraße 35, Universität Leipzig, 04103 Leipzig, Germany \\ ${ }^{5}$ Forschungsinstitut und Naturmuseum Senckenberg, Senckenberganlage 25, 60325 Frankfurt, Germany \\ ${ }^{6}$ Geology Department, Makerere University, P.O. Box 7062, Uganda
}

Correspondence to: G. Brügmann (bruegmag@uni-mainz.de)

Received: 13 February 2012 - Published in Biogeosciences Discuss.: 23 March 2012

Revised: 26 October 2012 - Accepted: 30 October 2012 - Published: 26 November 2012

\begin{abstract}
This study demonstrates that alkaline earth elements in enamel of hippopotamids, in particular $\mathrm{Ba}$ and $\mathrm{Sr}$, are tracers for water provenance and hydrochemistry in terrestrial settings. The studied specimens are permanent premolar and molar teeth found in modern and fossil lacustrine sediments of the Western Branch of the East African Rift system (Lake Kikorongo, Lake Albert, and Lake Malawi) and from modern fluvial environments of the Nile River.

Concentrations in enamel vary by two orders of magnitude for Ba $\left(120-9336 \mu \mathrm{g} \mathrm{g}^{-1}\right)$ as well as for $\mathrm{Sr}\left(9-2150 \mu \mathrm{g} \mathrm{g}^{-1}\right)$. The variations are partially induced during post-mortem alteration and during amelogenesis, but the major contribution originates ultimately from the variable water chemistry in the habitats of the hippopotamids which is controlled by the lithologies and weathering processes in the watershed areas. Amelogenesis causes a distinct distribution of $\mathrm{MgO}, \mathrm{Ba}$ and $\mathrm{Sr}$ in modern and fossil enamel, in that element concentrations increase along profiles from the outer rim towards the enamel-dentin junction by a factor of 1.3-1.9. These elements are well correlated in single specimens, thus suggesting that their distribution is determined by a common, single process, which can be described by closed system Rayleigh crystallization of bioapatite in vivo.
\end{abstract}

Enamel from most hippopotamid specimens has $\mathrm{Sr} / \mathrm{Ca}$ and $\mathrm{Ba} / \mathrm{Ca}$ which are typical for herbivores. However, $\mathrm{Ba} / \mathrm{Sr}$ ranges from 0.1 to 3 and varies on spatial and temporal scales. Thus, $\mathrm{Sr}$ concentrations and $\mathrm{Ba} / \mathrm{Sr}$ in enamel differentiate between habitats having basaltic mantle rocks or Archean crustal rocks as the ultimate sources of $\mathrm{Sr}$ and $\mathrm{Ba}$. This provenance signal is modulated by climate change. In Miocene to Pleistocene enamel from the Lake Albert region, $\mathrm{Ba} / \mathrm{Sr}$ decreases systematically with time from 2 to 0.5 . This trend can be correlated with changes in climate from humid to arid, in vegetation from $\mathrm{C}_{3}$ to $\mathrm{C}_{4}$ biomass as well as with increasing evaporation of the lake water. The most plausible explanation is that Ba mobility decreased with increasing aridification due to preferential deposition with clay and Feoxide-hydroxide or barite on the watershed of Lake Albert.

\section{Introduction}

Alkaline earth elements are valuable proxies in studies on marine and terrestrial environments because they trace the water chemistry and can be used to reconstruct provenance characteristics of seawater and terrestrial water reservoirs or life histories of organisms. In lacustrine and fluvial 
environments $\mathrm{Ba}$ and $\mathrm{Sr}$ concentrations and their isotopic compositions are used to monitor element cycling in watersheds taking into account the effects of climate and tectonic processes on the weathering of different lithologies and on soil formation (Cameron et al., 1995; Dupre et al., 1996; Gaillardet et al., 1997; Shiller, 1997; White et al., 1999; Land et al., 2000; Dalai et al., 2002, 2003; Riebe et al., 2004; Garzanti et al., 2010, 2011; Padoan et al., 2011). As a general rule, $\mathrm{Ca}, \mathrm{Na}$ and $\mathrm{Sr}$ are more easily mobilized and removed from the watershed by groundwater and rivers than $\mathrm{Mg}$ and $\mathrm{Ba}$. The reason is that the latter metals are either incorporated in, or preferentially exchanged and adsorbed on secondary clay minerals, such as illite, chlorite, smectite, and, therefore, are retained in the weathering cycle (Nesbitt et al., 1980; Kronberg et al., 1987). In many large watersheds the limited Ba mobility is reflected in the dissolved fraction of ground water and rivers having lower $\mathrm{Ba} / \mathrm{Sr}$ than the parent lithologies, whereas the suspended load and sediments show the complementary ratio (Dupre et al., 1996; Dalai et al., 2002, 2003). Intensive weathering, however, may replace the clay minerals by phases having low exchange capacities, for example kaolinite and hydroxides, causing more effective Ba mobilization by ground or with river waters (Kronberg et al., 1987). Yet, the presence of sulfate ions and saline waters may favor the stability of hardly soluble barite which minimizes Ba loss from the catchment area (Hanor, 2000).

The alkaline earth metals $\mathrm{Mg}, \mathrm{Sr}$ and $\mathrm{Ba}$ can substitute $\mathrm{Ca}$ in calcified biogenic and inorganic hard tissues, such as calcite, aragonite or apatite. Calcified materials mostly grow incrementally adding on daily, seasonal and annual scales new mineralized layers. The alkaline earth elements store information on both ambient environmental chemistry and physiological conditions during the calcification process. These archives can be used to reconstruct chronologies of metal concentrations, dietary habits, migration paths, paleoclimate and -environmental changes in marine and terrestrial settings by performing high-resolution chemical and isotope analyzes. For example ancient ocean salinity and sea surface temperature have been estimated using $\mathrm{Sr} / \mathrm{Ca}, \mathrm{Ba} / \mathrm{Ca}$ and $\mathrm{Mg} / \mathrm{Ca}$ with $\delta^{18} \mathrm{O}$ determinations in corals, foraminifera, otholiths and fish scales (McCulloch et al., 1994; Lear et al., 2000; Balter and Lécuyer, 2010). These proxies also trace water reservoirs allowing the reconstruction of fish movements between freshwater, estuarine, marine and saline habitats (Wells et al., 2003; McCulloch et al., 2005; Elsdon and Gillanders, 2006; Milton et al., 2008; Balter and Lécuyer, 2010; Phillis et al., 2011).

An important observation is the stepwise evolution of $\mathrm{Ba} / \mathrm{Ca}$ and $\mathrm{Sr} / \mathrm{Ca}$ in terrestrial ecosystems which has been used to reconstruct trophic levels and the feeding habits of mammals in ancient ecosystems (Elias et al., 1982; Sillen, 1988; Sillen and Lee-Thorp, 1994; Burton et al., 1999; Blum et al., 2000; Balter et al., 2002; Balter, 2004). Thus, Sr/Ca and $\mathrm{Ba} / \mathrm{Ca}$ in bones and teeth can be used to distinguish herbivory, carnivory and insectivory as well as browsing and grazing herbivores. This differentiation relies on the process of biopurification, which discriminates against $\mathrm{Sr}$ and $\mathrm{Ba}$ relative to $\mathrm{Ca}$ along the food chain. Discrimination between $\mathrm{Ba}$ and $\mathrm{Sr}$, though, appears to be inefficient in single habitats. In different ecosystems $\mathrm{Sr} / \mathrm{Ca}$ and $\mathrm{Ba} / \mathrm{Ca}$ evolve along almost parallel trends each having a distinct $\mathrm{Ba} / \mathrm{Sr}$ (Balter, 2004). Thus, $\mathrm{Ba} / \mathrm{Sr}$ in bones and teeth tissues probably represents a regional diet average.

Post-mortem, during fossilization and diagenesis, chemical components from the sediment and its interstitial water may migrate into the pore spaces of bones and teeth and become adsorbed at the surface of the apatite crystals and eventually incorporated into the mineral lattice (Millard and Hedges, 1996; Trueman et al., 2004; Kohn, 2008; Tütken et al., 2008). The structure of bone and dentin is rather porous because it contains only about $70 \mathrm{wt} \%$ of the mineral component. In contrast, enamel contains about $96 \mathrm{wt} \%$ of apatite leaving only a small volume for intruding diagenetic fluids (Pasteris et al., 2008). This explains why many studies observe that the chemical composition of enamel remains better preserved than that of bone and dentin during diagenesis (Hoppe et al., 2003; Sponheimer and Lee-Thorp, 2006; Tütken et al., 2008; Domingo et al., 2009; Brügmann et al., 2012). Certain element concentrations of fossil enamel, however, are often severely modified during diagenesis. The secondary precipitation of Fe- and Mn-oxides and oxyhydroxides is a common process as well as the addition of $F$ and the recrystallization to fluorapatite. The effect of diagenesis on the $\mathrm{Sr}$ and $\mathrm{Ba}$ distribution in bone and teeth is often severe and even the application of sequential leaching techniques in order to recover the primary biogenic component does not provide reliable results (Koch et al., 1992; Hoppe et al., 2003; Lee-Thorp and Sponheimer, 2003).

Here we complement the study of Brügmann et al. (2012) describing the major element variation in Neogene hippopotamid teeth from the East African Rift system (EARS) by discussing the distribution of alkaline earth elements, in particular those of $\mathrm{Sr}$ and $\mathrm{Ba}$, in enamel. The results show that although alteration and vital effects during amelogenesis have significant impact on the element distribution, the largest influence on concentration variations are induced by external environmental conditions, such as water provenance and hydrochemistry, and climate.

\section{Samples and methods}

\subsection{Samples}

Given the large compositional variation in plants, bioapatite from migrating herbivores, such as elephants, rhinoceros, or bovids, would be an unsuitable target in order to identify the signature of discrete ecosystems or habitats. More promising is bioapatite from non-migratory animals, such as hippopotamids. Extant species (Hippopotamus amphibius, 
Choeropsis liberensis) have terrestrial foraging habits, are water-dependent and adapted to a variety of different habitats ranging from lakes to rivers, and from freshwater to saline and brackish environments (Eltringham and Barrett, 2010; Chansa et al., 2011a, b). Recent studies confirm that fossil species primarily fed on terrestrial plant assemblages, such as $\mathrm{C}_{4}$ or $\mathrm{C}_{3}$ grasses (e.g. Boisserie and Merceron, 2011). The high abundances of fossil hippopotamid remains in river and lacustrine basin deposits indicate that the ancestral forms were also adapted to a semi-aquatic life similar to their modern analogues (Boisserie et al., 2005; Cerling et al., 2008; Harris et al., 2008). Hippopotamid teeth are chemically robust environmental archives and are common mammalian fossils in African terrestrial sediments. It is expected that the chemical composition of bioapatite forming the tooth is reflected in the chemical composition of the diet (food and drinking water), but it also depends on tooth type and stage of development. During infancy maternal food sources and underdeveloped physiology may compromise the environmental signal. In order to avoid these effects, we only analyzed permanent premolar and molar teeth from 24 different animals. They have been sampled from various habitats in Eastern Africa, representing modern and fossil ( $\leq 6.5 \mathrm{Ma}$ ) lacustrine settings (Lake Albert and Lake Kikorongo in Uganda; Lake Malawi in Malawi), and modern fluvial environments (Blue, White, and Upper Nile in the Sudan). The modern teeth belong to the species Hippopotamus amphibius. Some of the fossil teeth collected in Uganda, however, are conspicuous for their small size and are for the time being classified as "Small hippopotamids" (Boisserie et al., 2005). Sampling locations and the geological ages of the studied specimens have been described in detail by Brachert et al. (2010) and Brügmann et al. (2012). The freshwater lakes Lake Albert and Lake Malawi belong to the western branch of the EARS. The tectonic history as well as litho- and biostratigraphy of the lakes have been comprehensively described (Pickford et al., 1993; Senut and Pickford, 1994; Betzler and Ring, 1995; Ring and Betzler, 1995; Beuning et al., 1997; Van Damme and Pickford, 2003; Bobe et al., 2007).

\subsection{Analytical methods}

Trace element analysis by laser ablation - inductively coupled plasma mass spectrometry (LA-ICPMS)

New Wave Nd-YAG laser systems with wavelengths of $193 \mathrm{~nm}$ and $213 \mathrm{~nm}$ were used for the ablation in order to determine $\mathrm{Ba}$ and $\mathrm{Sr}$ concentrations in the bioapatite of the tooth specimens. Ablation craters with a diameter of $80 \mu \mathrm{m}$ were produced applying a laser frequency of $10 \mathrm{~Hz}$ and energies between 2 and $8 \mathrm{~J} \mathrm{~cm}^{-2}$. Helium carried the ablated material into a ThermoFinnigan Element2 sector field ICPMS which was run in the low resolution mode. Counting time amounted to $20 \mathrm{~s}$ on the background and 80 to $100 \mathrm{~s}$ on the sample. NIST612 and KL2-G glasses were reference materi- als and ${ }^{43} \mathrm{Ca}$ the internal standard. The trace element measurements were done on the same spots where major elements have been determined by Brügmann et al. (2012), although with larger diameters. The measured $\mathrm{CaO}$ content has been used as an internal reference for $\mathrm{Ba}$ and $\mathrm{Sr}$ analyses. The analytical procedure is described in detail by (Jochum et al., 2006, 2007). The detection limit for $\mathrm{Ba}$ and $\mathrm{Sr}$ is better than $500 \mathrm{ng} \mathrm{g}^{-1}$, and this is at least two orders of magnitude lower than the measured concentrations in the samples. The measured standard data agree with published compilation values within $95 \%$ confidence limits (Jochum et al., 2007). Brügmann et al. (2012) also measured Sr concentrations by electron microprobe. A regression line for both data sets indicates an average difference of about $10 \%$, which is within the analytical error of the electron probe analyzes. The $\mathrm{MgO}, \mathrm{CaO}$, and $\mathrm{Na}_{2} \mathrm{O}$ data discussed in the following paragraphs are from Brügmann et al. (2012) and have been determined using the electron microprobe.

\section{Results}

The complete set of laser ablation data of $\mathrm{Ba}$ and $\mathrm{Sr}$ is provided in Table S1 of the Supplement. Table 1 summarizes average concentrations of the alkaline earth metals $\mathrm{CaO}, \mathrm{MgO}, \mathrm{Ba}$, and $\mathrm{Sr}$ in enamel, cement and dentin. Overall, $\mathrm{Sr}$ and $\mathrm{Ba}$ display vast concentration variations in all tooth tissues. For example, Ba concentrations in enamel vary from 9 to $2150 \mu \mathrm{g} \mathrm{g}^{-1}$ and those of Sr vary from 120 to $9336 \mu \mathrm{g} \mathrm{g}^{-1}$. The coefficient of variation (COV) of Ba and $\mathrm{Sr}$ in enamel and dentin is between 0.8 and 1.0 and is significantly higher than that of $\mathrm{CaO}$ or $\mathrm{MgO}(\mathrm{COV}<0.45)$. The concentration variation in cement tissue is smaller than that in enamel (COV of cement: $\sim 0.55$ for Ba and $\mathrm{Sr}$ ) but it is still higher than that of $\mathrm{CaO}$, and $\mathrm{MgO}$ in cement $(\mathrm{COV}<0.4$; Brügmann et al., 2012). However, the relatively low number of analyzes (31; Table 1) might be not representative for this material.

Barium and $\mathrm{Sr}$ concentrations differ between modern and fossil specimens and among dentin and enamel. Modern enamel has on average lower $\mathrm{Ba}$ and $\mathrm{Sr}$ contents $\left(111 \mu \mathrm{g} \mathrm{g}^{-1}\right.$ and $437 \mu \mathrm{g} \mathrm{g}^{-1}$, respectively) than fossil enamel $\left(586 \mu \mathrm{g} \mathrm{g}^{-1}\right.$ and $1023 \mu \mathrm{gg}^{-1}$, respectively; Table 1; Fig. 1). This is also true for dentin, as fossil material has $\mathrm{Ba}$ and $\mathrm{Sr}$ concentrations of more than $900 \mu \mathrm{g} \mathrm{g}^{-1}$, whereas modern dentin has less than $450{\mu \mathrm{g} \mathrm{g}^{-1}}$ (Table 1; Fig. 1). In teeth of recent animals average $\mathrm{Sr}$ concentrations in dentin tend to be lower than in enamel (Table 1; Fig. 1a). This becomes evident at the enamel-dentin junction (EDJ), where $\mathrm{Sr}$ concentrations in modern teeth abruptly decrease (Fig. 2a), but increase sharply by a factor of about two in fossil specimens (Fig. 2b).

The large range of $\mathrm{Ba}$ and $\mathrm{Sr}$ concentrations reflect the enormous differences among teeth from different geographical locations and the systematic variations within single tooth specimens (Fig. 2). The enamel from teeth found along the 
Table 1. Average concentrations of alkaline earth elements in modern and fossil hippopotamid enamel, dentin and cement.

\begin{tabular}{|c|c|c|c|c|c|c|c|c|c|c|c|c|c|c|c|c|}
\hline Enamel Averages & $\begin{array}{r}\text { Age } \\
\text { (Ma) }\end{array}$ & $N$ & $\begin{array}{r}\mathrm{Ba} \\
\mu \mathrm{gg}^{-1}\end{array}$ & $1 \sigma$ & $\mu \mathrm{gg}^{\mathrm{Sr}}$ & $1 \sigma$ & $\begin{array}{l}\mathrm{CaO} \\
\text { wt } \%\end{array}$ & $1 \sigma$ & $\begin{array}{r}\mathrm{MgO} \\
\text { wt } \%\end{array}$ & $1 \sigma$ & $\mathrm{Ba} / \mathrm{Sr}$ & $1 \sigma$ & $\begin{array}{r}\mathrm{Sr} / \mathrm{Ca} \\
* 1000\end{array}$ & $1 \sigma$ & $\begin{array}{l}\mathrm{Ba} / \mathrm{Ca} \\
* 1000\end{array}$ & $1 \sigma$ \\
\hline All specimens & & 1408 & 388 & 374 & 767 & 778 & 54.52 & 0.76 & 0.34 & 0.14 & 0.61 & 0.54 & 1.97 & 1.99 & 1.00 & 0.96 \\
\hline All fossil & & 811 & 586 & 382 & 1023 & 935 & 54.57 & 0.85 & 0.27 & 0.12 & 0.85 & 0.60 & 2.66 & 2.39 & 1.53 & 0.98 \\
\hline All modern & & 490 & 111 & 65 & 437 & 177 & 54.47 & 0.66 & 0.40 & 0.09 & 0.25 & 0.12 & 1.12 & 0.46 & 0.29 & 0.17 \\
\hline All Nile & & 102 & 58 & 51 & 271 & 119 & 54.36 & 0.34 & 0.35 & 0.09 & 0.18 & 0.09 & 0.70 & 0.30 & 0.15 & 0.13 \\
\hline Upper Nile-1 & & 24 & 16 & 6 & 166 & 27 & 54.28 & 0.16 & 0.27 & 0.07 & 0.095 & 0.02 & 0.43 & 0.07 & 0.04 & 0.01 \\
\hline Upper Nile-2 & & 25 & 70 & 14 & 318 & 25 & 54.17 & 0.22 & 0.32 & 0.05 & 0.220 & 0.03 & 0.82 & 0.07 & 0.18 & 0.04 \\
\hline White Nile-3 & & 29 & 19 & 8 & 172 & 24 & 54.20 & 0.26 & 0.47 & 0.04 & 0.11 & 0.03 & 0.44 & 0.06 & 0.05 & 0.02 \\
\hline Blue Nile-4 & & 24 & 132 & 39 & 447 & 36 & 54.83 & 0.22 & 0.32 & 0.03 & 0.29 & 0.06 & 1.14 & 0.09 & 0.34 & 0.10 \\
\hline Zoo spec. S276 & & 168 & 111 & 28 & 393 & 46 & 54.94 & 0.46 & 0.38 & 0.08 & 0.28 & 0.06 & 1.00 & 0.12 & 0.28 & 0.07 \\
\hline Lake Malawi modern & & 149 & 103 & 58 & 592 & 213 & 54.40 & 0.56 & 0.44 & 0.08 & 0.16 & 0.05 & 1.52 & 0.56 & 0.26 & 0.15 \\
\hline Lake Malawi fossil & & 77 & 576 & 285 & 913 & 137 & 54.94 & 0.38 & 0.28 & 0.04 & 0.62 & 0.28 & 2.32 & 0.35 & 1.47 & 0.73 \\
\hline Lake Albert modern & & 71 & 206 & 54 & 457 & 46 & 53.71 & 0.77 & 0.44 & 0.08 & 0.45 & 0.08 & 1.19 & 0.12 & 0.54 & 0.14 \\
\hline All Lake Albert fossil & & 599 & 633 & 405 & 624 & 206 & 54.40 & 0.89 & 0.22 & 0.06 & 1.04 & 0.57 & 1.62 & 0.54 & 1.67 & 1.04 \\
\hline 5106 & 1.30 & 22 & 389 & 275 & 672 & 64 & 55.29 & 0.42 & 0.16 & 0.05 & 0.56 & 0.36 & 1.70 & 0.16 & 0.99 & 0.70 \\
\hline GPS421 & 1.80 & 60 & 216 & 112 & 608 & 217 & 53.53 & 0.78 & 0.23 & 0.06 & 0.36 & 0.09 & 1.59 & 0.57 & 0.56 & 0.29 \\
\hline GPS165 & 1.80 & 46 & 502 & 242 & 687 & 78 & 55.35 & 0.38 & 0.26 & 0.04 & 0.72 & 0.31 & 1.74 & 0.20 & 1.27 & 0.61 \\
\hline 5306 & 2.30 & 83 & 248 & 42 & 505 & 72 & 54.04 & 0.76 & 0.32 & 0.06 & 0.49 & 0.06 & 1.29 & 0.14 & 0.61 & 0.07 \\
\hline GPS405 & 3.45 & 48 & 601 & 122 & 791 & 133 & 53.97 & 0.85 & 0.23 & 0.04 & 0.76 & 0.06 & 2.05 & 0.34 & 1.56 & 0.31 \\
\hline GPS387 & 3.45 & 30 & 688 & 103 & 551 & 64 & 54.20 & 0.33 & 0.22 & 0.04 & 1.26 & 0.18 & 1.42 & 0.17 & 1.77 & 0.26 \\
\hline 1706 & 4.00 & 28 & 1087 & 334 & 874 & 90 & 54.37 & 0.98 & 0.21 & 0.04 & 1.23 & 0.28 & 2.25 & 0.22 & 2.79 & 0.84 \\
\hline GPS396 & 4.00 & 55 & 643 & 171 & 836 & 180 & 53.65 & 0.70 & 0.16 & 0.03 & 0.76 & 0.06 & 2.18 & 0.48 & 1.68 & 0.45 \\
\hline 2106 & 5.50 & 30 & 878 & 290 & 453 & 85 & 54.87 & 0.27 & 0.20 & 0.03 & 1.90 & 0.35 & 1.15 & 0.22 & 2.24 & 0.74 \\
\hline 5006 & 5.50 & 32 & 1803 & 205 & 918 & 182 & 54.85 & 0.28 & 0.20 & 0.04 & 2.03 & 0.16 & 2.34 & 0.47 & 4.60 & 0.52 \\
\hline 1906 & 6.30 & 42 & 559 & 116 & 328 & 51 & 55.43 & 0.46 & 0.19 & 0.04 & 1.71 & 0.29 & 0.83 & 0.13 & 1.41 & 0.29 \\
\hline 2806 & 6.30 & 33 & 767 & 95 & 636 & 34 & 54.90 & 0.30 & 0.19 & 0.04 & 1.21 & 0.14 & 1.62 & 0.09 & 1.96 & 0.2 \\
\hline 3206 & 6.50 & 26 & 793 & 217 & 474 & 101 & 54.44 & 0.43 & 0.23 & 0.04 & 1.66 & 0.16 & 1.22 & 0.26 & 2.04 & 0.56 \\
\hline 2706 & 6.50 & 15 & 850 & 347 & 529 & 38 & 55.51 & 0.24 & 0.23 & 0.03 & 1.61 & 0.68 & 1.33 & 0.10 & 2.14 & 0.88 \\
\hline 0706 & 6.50 & 49 & 668 & 173 & 530 & 177 & 53.88 & 0.49 & 0.22 & 0.04 & 1.29 & 0.28 & 1.38 & 0.46 & 1.73 & 0.45 \\
\hline Lake Kikorongo & 0.01 & 135 & 384 & 231 & 2860 & 987 & 55.08 & 0.53 & 0.47 & 0.14 & 0.13 & 0.05 & 7.26 & 2.48 & 0.98 & 0.58 \\
\hline Dentin Average & & 197 & 1236 & 983 & 1671 & 1582 & 54.45 & 4.19 & 1.15 & 1.52 & 0.88 & 0.81 & 4.18 & 3.75 & 3.16 & 2.52 \\
\hline Cement Average & & 31 & 304 & 164 & 423 & 231 & 52.82 & 2.60 & 1.05 & 0.42 & 0.75 & 0.25 & 1.14 & 0.70 & 0.81 & 0.45 \\
\hline
\end{tabular}

$N$ : number of analyses; Data of $\mathrm{CaO}$ and $\mathrm{MgO}$ from Brügmann et al. (2012).

river Nile has on average the lowest $\mathrm{Ba}$ and $\mathrm{Sr}$ concentrations (58 $\mu \mathrm{g} \mathrm{g}^{-1}$ and $271 \mu \mathrm{g} \mathrm{g}^{-1}$, respectively), but specimens from Lake Albert ( $633 \mu \mathrm{g} \mathrm{g}^{-1} \mathrm{Ba}$ ) and Lake Kikorongo $\left(2860 \mathrm{\mu g} \mathrm{g}^{-1} \mathrm{Sr}\right.$ ) contain 10 times as much Ba and $\mathrm{Sr}$ (Fig. 2; Table 1). However, the enrichment of $\mathrm{Ba}$ and $\mathrm{Sr}$ does not necessarily run in parallel. For example, the tooth from Lake Kikorongo has the highest $\mathrm{Sr}$ concentration but its Ba concentration is the lowest among the fossil samples (Fig. 2b, d). Overall the correlation of $\mathrm{Sr}$ and $\mathrm{Ba}$ concentrations in the teeth is very poor $\left(R^{2}=0.055\right.$ in enamel). Even the concentration variations of these elements among specimens from single settings, such as Lake Albert, Lake Malawi or the Nile River, vary: $50 \%$ to $90 \%$ for $\mathrm{Ba}$, and $30 \%$ to $45 \%$ for $\mathrm{Sr}$ (Table 1).

In a single specimen the standard deviation follows a similar pattern in that $\mathrm{Ba}$ in enamel varies by $60 \%$ to $11 \%$, whereas Sr only varies from 35 to $5 \%$ (Table 1). Thus, this variation is significantly smaller than that observed on a regional scale and therefore diagenetic overprint should not be the major cause for the large differences observed between sample locations. The variation in single specimens reflects the systematic increase of $\mathrm{Ba}$ and $\mathrm{Sr}$ concentrations from the outside enamel rim towards the EDJ (Fig. 2). This is seen in apical and cervical profiles of enamel. Indeed the $\mathrm{Ba}$ and $\mathrm{Sr}$ concentrations as well as the concentration gradients along such profiles are very similar (Fig. 2; apical and cervical profiles are shown from specimens from modern Lake Malawi and Lake Albert and fossil Lake Kikorongo and Lake Malawi). This implies that these animals did not experience a significant diet change at least until the end of molar and premolar amelogenesis. Similar element distributions in enamel have been observed for $\mathrm{Na}_{2} \mathrm{O}$ and $\mathrm{MgO}$, whereas $\mathrm{Cl}$ displays the opposite trend and $\mathrm{CaO}$ is constant along such a profile (Brügmann et al., 2012). In modern specimens the enrichment towards the EDJ is highest for $\mathrm{Ba}(1.93 \pm 0.41$; enrichment is defined as the concentration ratio of the average of the outer $30 \%$ to the inner $30 \%$ of the enamel width), whereas that of $\mathrm{Sr}$ is about $1.39 \pm 0.13$ and similar to that of $\mathrm{MgO}$ and $\mathrm{Na}_{2} \mathrm{O}$. The similar distribution for $\mathrm{Sr}$, $\mathrm{Na}_{2} \mathrm{O}$ and $\mathrm{MgO}$ is confirmed by $\mathrm{Sr} / \mathrm{MgO}$ and $\mathrm{Sr} / \mathrm{Na}_{2} \mathrm{O}$ ratios close to unity $( \pm 10 \%)$, whereas ratios involving $\mathrm{Ba}$ are higher (1.3 and $1.4 \pm 20 \%$, respectively). In fossil specimens the enrichment factors tend to be smaller (Ba: $1.42 \pm 0.61$, Sr: $1.22 \pm 0.24)$ but they are more variable. These lower ratios are due to $\mathrm{Sr}$ and $\mathrm{Ba}$ enrichment of many outer enamel 


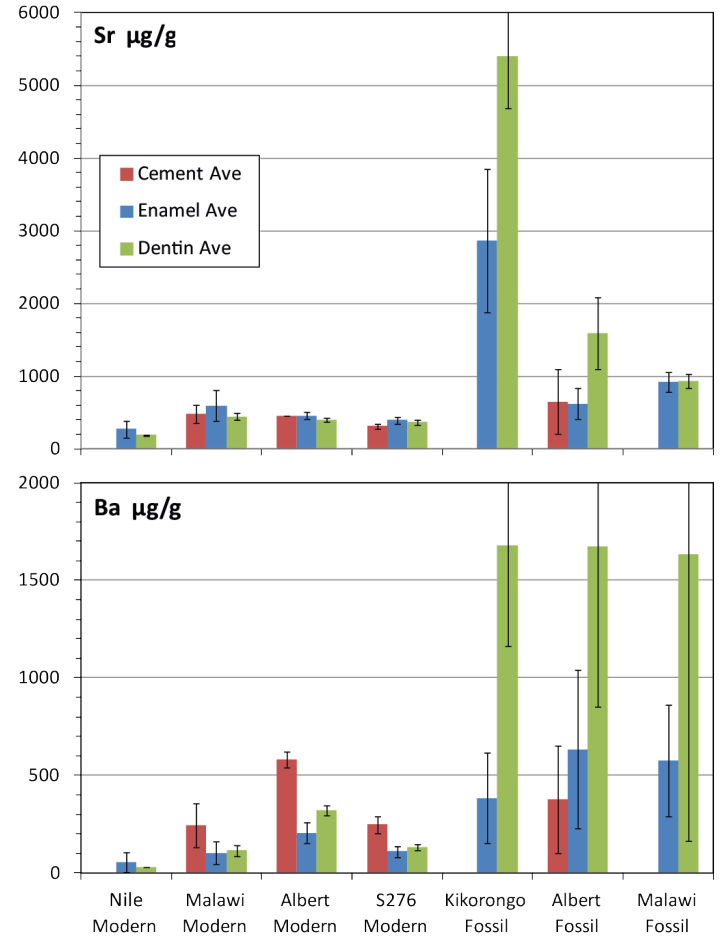

Fig. 1. Average $\mathrm{Ba}$ and $\mathrm{Sr}$ concentrations in cement, enamel and dentin of modern and fossil hippopotamid teeth. Error bars represent the $1 \sigma$ error of the average.

rims and may indicate secondary addition of $\mathrm{Sr}$ and $\mathrm{Ba}$ during diagenesis.

There are no systematic variations in dentin and cement that could be related to the formation of these tissues or to environmental influences. Therefore, we will focus the discussion on the element distribution in enamel, of single specimens and among specimens.

\section{Discussion}

In order to evaluate the sensitivity of trace elements with regard to environmental change, it is necessary to decode the changes induced by bioapatite deposition during tooth development from those imposed externally by changing diet composition at different geographical and geochronological scales. Overall, $\mathrm{Sr}$ and Ba have similar COV values of about 1 and their concentrations are highly variable if compared with those of $\mathrm{MgO}$ and $\mathrm{Na}_{2} \mathrm{O}\left(\mathrm{COV}(\mathrm{MgO})=0.42 ; \mathrm{COV}\left(\mathrm{Na}_{2} \mathrm{O}\right)\right.$ $=0.25$ ). The low $\mathrm{COV}$ of $\mathrm{Na}_{2} \mathrm{O}$, like that of $\mathrm{CaO}$, suggests that the abundance of this element in enamel is very well controlled by the physiology of the hippopotamid that does not accommodate diet provoked variations. In contrast, the increasing $\mathrm{COV}$ of $\mathrm{MgO}, \mathrm{Sr}$ and $\mathrm{Ba}$, may indicate an increasing sensitivity to environmental changes.
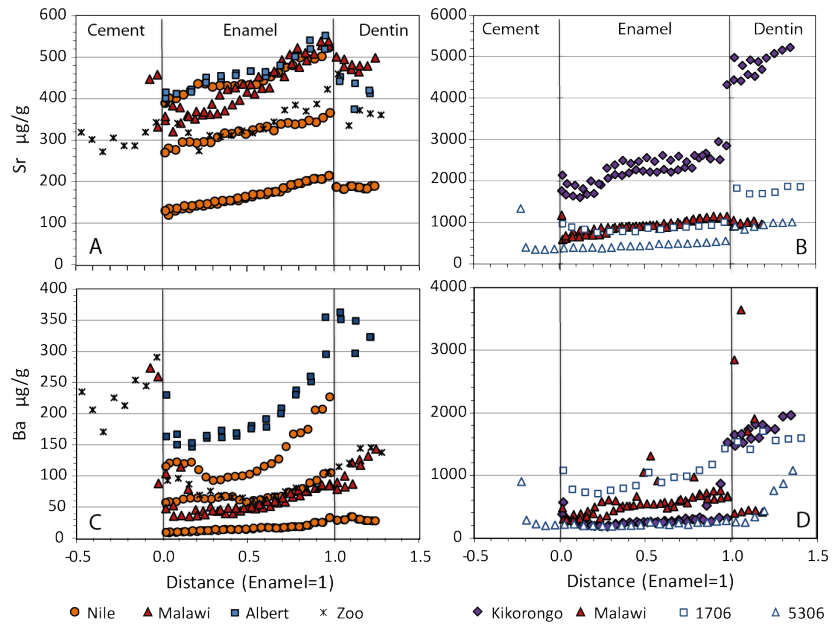

Fig. 2. $\mathrm{Ba}$ and $\mathrm{Sr}$ variations along selected tooth profiles from the outside margin through cementum, enamel into dentin. Several specimens (modern and fossil Malawi; modern Lake Albert; Lake Kikorongo) are represented by data along apical and cervical profile locations. Significant differences of concentrations and gradients are not observed. The distance is normalized to the length of the enamel $=1$. (a, c) Ba and $\mathrm{Sr}$ variation in modern enamel. $(\mathbf{b}, \mathbf{d})$ $\mathrm{Ba}$ and $\mathrm{Sr}$ variation in fossil enamel.

In individual specimens $\mathrm{Ba}$ concentrations are more variable than those of $\mathrm{Sr}$ (average $\mathrm{COV}(\mathrm{Ba})=0.4$; average $\mathrm{COV}(\mathrm{Sr})=0.25)$. The concentration variations of $\mathrm{MgO}$ and $\mathrm{Na}_{2} \mathrm{O}$ are lower and rather similar (average $\mathrm{COV}=0.2$; Brügmann et al., 2012). These variations in individual specimens are controlled by the mechanisms of tooth formation and diagenetic remobilization.

\subsection{Concentration variations in single specimens: recognizing alteration and implications for amelogenesis}

\subsubsection{Recognizing secondary redistribution of $\mathrm{Ba}$ and $\mathrm{Sr}$}

Diagenetic overprint has been detected in many of the studied specimens (Brügmann et al., 2012). Fluorine, Fe and Mn are always added during diagenesis obscuring their primary distribution. However, major components, such as $\mathrm{CaO}, \mathrm{P}_{2} \mathrm{O}_{5}$, $\mathrm{MgO}$ or $\mathrm{Na}_{2} \mathrm{O}$, indicate minimal remobilization in most specimens. Along all profiles through modern enamel $\mathrm{Ba}$ and Sr concentrations systematically increase towards the EDJ (Fig. 2a, c). However, in most fossil specimens anomalous high concentrations of both elements occur near the outside rim of the tooth $(0-300 \mu \mathrm{m})$ and within $200 \mu \mathrm{m}$ of the EDJ (Fig. 2b, d). Barium and Sr are known to become enriched in bone and tooth tissues when being exposed to postmortem alteration (Koch et al., 1992; Sandrock et al., 1999; Hoppe et al., 2003; Lee-Thorp and Sponheimer, 2003). In order to evaluate the influence of alteration on the distribution 
of these elements, we performed linear regression analyzes for data along the enamel profiles perpendicular to the EDJ. Enamel from different tooth specimens or from different parts within single specimens has variable thicknesses $(2-$ $4 \mathrm{~mm})$ and therefore enamel thickness $(x)$ is normalized to 1. Regression lines are calculated with data between $x=0.2$ and $x=0.9$ (up to $600 \mu \mathrm{m}$ away from the enamel rim and up to $200 \mu \mathrm{m}$ away from the EDJ) in order to avoid potentially altered enamel fractions. Using the linear equations, we calculated the expected $\mathrm{Ba}$ and $\mathrm{Sr}$ concentrations near the enamel rim (at point 0.1 ) and compared these values with the averages of the measured concentrations within the range 0 0.2. In modern enamel calculated and measured Sr concentrations agree very well plotting along the $1: 1$ line (Fig. 3). Many fossil enamel specimens follow this trend, in particular those where enamel is enclosed by cement tissue or the profiles were measured within deep folds of the tooth crown, surrounded by dentin. In cases where enamel is at the surface of the tooth, directly exposed to the sedimentary environment, significant $\mathrm{Sr}$ enrichment ranging up to a factor of two has been detected (Fig. 3a). A few examples also suggest $\mathrm{Sr}$ depletion relative to the expected primary concentration.

The $\mathrm{Ba}$ distribution is rather complex even in modern enamel. Comparing measured and expected Ba concentrations near the rim, fossil and modern enamel can be enriched in Ba up to a factor of three (Figs. 2c, d, 3b). Several modern specimens show a concentration increase near the outside enamel rim and in a few cases the trend of Ba enrichment towards the EDJ appears to be exponential rather than linear (Fig. 2). Therefore, the linear regression models tend to underestimate the true $\mathrm{Ba}$ concentration near the enamel rim (for example specimen Alb10-1/2AB from Lake Albert, Fig. 2c). This explains that even data from modern enamel plot above the $1: 1$ line in Fig. 3. In some modern specimens, however, Ba concentrations de facto increase at the outer rim (specimens Nile-4, S276, Mal 8.1-1AB; Fig. 2a, c). Because the modern specimen had not been in contact with sediments, this must be a primary feature developed during the live time of the hippopotamid. Possibly, during or after eruption the enamel equilibrates with salvia and these elements diffuse through the pore spaces and become adsorbed at the surface of the bioapatite crystallites. Alternatively, this feature is the result of a diet change during the late stages of amelogenesis. Barium enrichment at the outer rim is also seen in fossil enamel, but because of the uncertainty about the origin of $\mathrm{Ba}$ enrichment in modern enamel, it is not possible to identify unambiguously secondary $\mathrm{Ba}$ additions.

Fossil dentin has always higher $\mathrm{Sr}$ and Ba concentrations than modern dentin (Table 2; Fig. 1a, b) which implies secondary enrichment of dentin during diagenesis. The element distribution across the EDJ supports this conclusion. Whereas modern dentin has lower Sr concentrations than enamel, fossil material shows the opposite pattern. Similarly, Ba displays a continuous concentration trend across the EDJ in modern specimens (Fig. 2c). However, there is a well de-
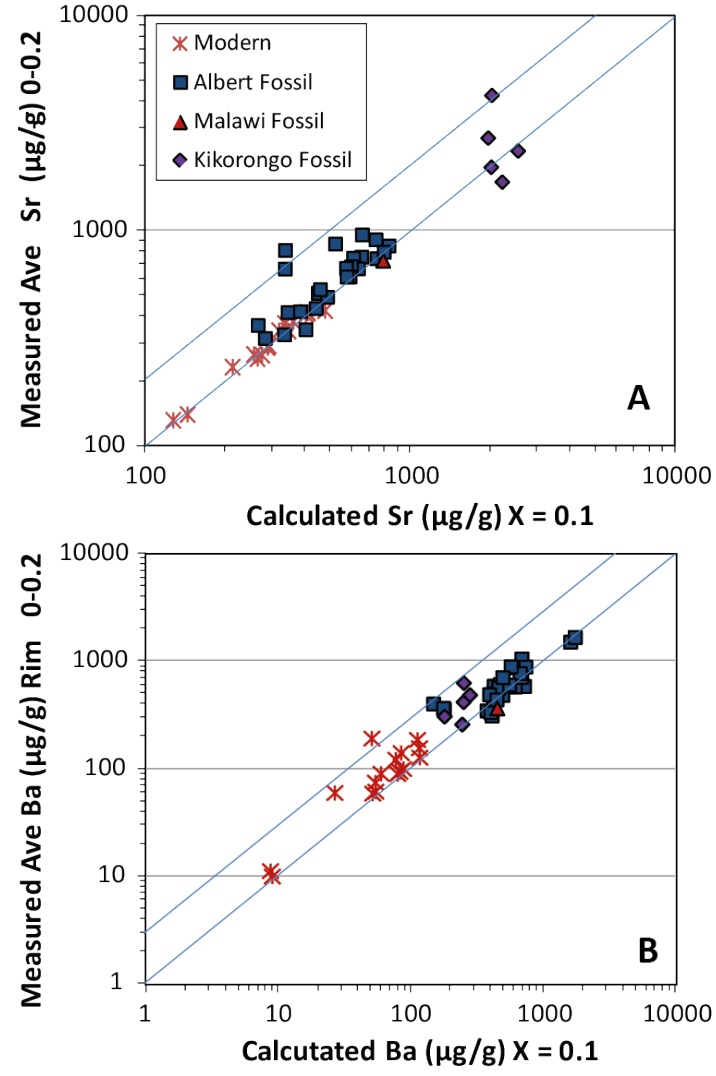

Fig. 3. Comparison of (a) $\mathrm{Sr}$ and (b) Ba concentrations measured at the outside enamel rim of single modern and fossil tooth specimens with values expected there based on linear regression analyzes. Values above or below the $1: 1$ line suggest secondary addition or removal, respectively, of $\mathrm{Ba}$ and Sr. For details see Sect. 4.1.1.

fined discontinuity in fossil teeth indicating either Ba loss or $\mathrm{Ba}$ addition in dentin relative to enamel during the fossilization process. If dentin is significantly enriched in $\mathrm{Ba}$ and $\mathrm{Sr}$, then sometimes even the nearby enamel has unexpectedly high $\mathrm{Ba}$ or $\mathrm{Sr}$ concentrations (Fig. 2b, d). This would indicate a post-mortem chemical exchange across the EDJ.

\subsubsection{Implications for amelogenesis}

Enamel development can be divided into two stages: the secretion and the maturation phase (Robinson et al., 1995; Smith and Nanci, 1995; Boskey, 2007; Pasteris et al., 2008; Simmer et al., 2010). During the first period, the final shape and the size of the tooth is established and ameloblasts deposit a matrix of proteins which confines the deposition of apatite (Smith, 1998; Margolis et al., 2006; Simmer et al., 2010). At the end of this phase enamel tissue consists mainly of organic and fluid components; the mineral proportion is small, possibly in the range of $14 \mathrm{wt} \%$ (Smith, 1998). Maturation starts at the EDJ after appositional growth is completed (Simmer et al., 2010) and it involves in essence the 
Table 2. Rayleigh crystallization model for enamel formation.

\begin{tabular}{|c|c|c|c|c|c|c|c|c|c|c|c|c|c|c|c|c|c|}
\hline & $* F$ & $\begin{array}{r}\mathrm{Na}_{2} \mathrm{O} \\
\text { wt \% }\end{array}$ & $\begin{array}{l}\mathrm{MgO} \\
\mathrm{wt} \%\end{array}$ & $\mu \mathrm{gg}^{-1}$ & $\mu \mathrm{g} \mathrm{g}^{-1}$ & $\begin{array}{r}\mathrm{Na}_{2} \mathrm{O} \\
\text { wt } \%\end{array}$ & $\begin{array}{l}\mathrm{MgO} \\
\text { wt \% }\end{array}$ & $\begin{array}{r}\mathrm{Ba} \\
\mu \mathrm{gg}^{-1}\end{array}$ & $\mu \mathrm{gg}^{\mathrm{Sr}}$ & $\begin{array}{r}\mathrm{Na}_{2} \mathrm{O} \\
\text { wt \% }\end{array}$ & $\begin{array}{l}\mathrm{MgO} \\
\text { wt \% }\end{array}$ & $\mu \mathrm{gg}^{-1}$ & $\mu \mathrm{gg}^{\mathrm{Sr}}$ & $\begin{array}{r}\mathrm{Na}_{2} \mathrm{O} \\
\text { wt } \%\end{array}$ & $\begin{array}{l}\mathrm{MgO} \\
\text { wt \% }\end{array}$ & $\mu \mathrm{gg}^{-1}$ & $\begin{array}{r}\mathrm{Sr} \\
\mu \mathrm{g} \mathrm{g}^{-1}\end{array}$ \\
\hline & & \multicolumn{4}{|c|}{ Lake Malawi (modern) } & \multicolumn{4}{|c|}{ Lake Albert (Fossil) } & \multicolumn{4}{|c|}{ Lake Kikorongo (fossil) } & \multicolumn{4}{|c|}{ Upper Nile-1 (modern) } \\
\hline \multicolumn{18}{|c|}{ Calculation of the fluid composition at the end of secretion } \\
\hline$* * D_{\mathrm{Ap} / \mathrm{Fl}}$ & & 1.2 & 1.2 & 1.25 & 1.15 & 1.2 & 1.2 & 1.25 & 1.15 & 1.2 & 1.2 & 1.25 & 1.15 & 1.2 & 1.2 & 1.25 & 1.15 \\
\hline$* * * C_{\text {Apatite }}$ & & 1.5 & 0.5 & 85 & 550 & 1.4 & 0.3 & 799 & 950 & 1.5 & 0.56 & 500 & 3800 & 1.6 & 0.4 & 25 & 215 \\
\hline$* * * C_{\text {Fluid }}$ & 0.86 & 1.29 & 0.43 & 71 & 489 & 1.20 & 0.26 & 664 & 845 & 1.29 & 0.48 & 415 & 3380 & 1.37 & 0.34 & 21 & 191 \\
\hline \multicolumn{18}{|c|}{ Calculation of apatite composition during maturation } \\
\hline \multirow{11}{*}{$* * * C_{\text {Apatite }}$} & 0.9 & 1.51 & 0.50 & 86 & 554 & 1.41 & 0.30 & 808 & 957 & 1.51 & 0.57 & 506 & 3826 & 1.51 & 0.50 & 86 & 554 \\
\hline & 0.8 & 1.50 & 0.50 & 85 & 550 & 1.40 & 0.30 & 799 & 950 & 1.50 & 0.56 & 500 & 3800 & 1.50 & 0.50 & 85 & 550 \\
\hline & 0.7 & 1.44 & 0.48 & 81 & 533 & 1.34 & 0.29 & 759 & 921 & 1.44 & 0.54 & 475 & 3684 & 1.44 & 0.48 & 81 & 533 \\
\hline & 0.6 & 1.40 & 0.47 & 78 & 521 & 1.30 & 0.28 & 730 & 900 & 1.40 & 0.52 & 457 & 3600 & 1.40 & 0.47 & 78 & 521 \\
\hline & 0.5 & 1.35 & 0.45 & 74 & 507 & 1.26 & 0.27 & 698 & 876 & 1.35 & 0.50 & 437 & 3503 & 1.35 & 0.45 & 74 & 507 \\
\hline & 0.4 & 1.29 & 0.43 & 70 & 490 & 1.20 & 0.26 & 660 & 847 & 1.29 & 0.48 & 413 & 3388 & 1.29 & 0.43 & 70 & 490 \\
\hline & 0.3 & 1.22 & 0.41 & 65 & 470 & 1.13 & 0.24 & 614 & 811 & 1.22 & 0.45 & 384 & 3245 & 1.22 & 0.41 & 65 & 470 \\
\hline & 0.2 & 1.12 & 0.37 & 59 & 442 & 1.05 & 0.22 & 555 & 763 & 1.12 & 0.42 & 347 & 3053 & 1.12 & 0.37 & 59 & 442 \\
\hline & 0.1 & 0.98 & 0.33 & 50 & 398 & 0.91 & 0.20 & 467 & 688 & 0.98 & 0.36 & 292 & 2752 & 0.98 & 0.33 & 50 & 398 \\
\hline & 0.05 & 0.85 & 0.28 & 42 & 359 & 0.79 & 0.17 & 392 & 620 & 0.85 & 0.32 & 246 & 2480 & 0.85 & 0.28 & 42 & 359 \\
\hline & 0.01 & 0.62 & 0.21 & 28 & 282 & 0.57 & 0.12 & 262 & 487 & 0.62 & 0.23 & 164 & 1948 & 0.62 & 0.21 & 28 & 282 \\
\hline
\end{tabular}

$* F$ : fraction of fluid remaining; $* * D$ : partition coefficient Apatite/Fluid; $* * * C$ : concentration (wt $\%$ ) of fluid or apatite.

enlargement of the existing crystallites by replacing protein and fluid with bioapatite (Robinson et al., 1995). Enamel formation is finished at the time of tooth eruption, thus this tissue is metabolically inactive afterwards.

Beyond the rims of altered enamel, $\mathrm{Ba}, \mathrm{Sr}, \mathrm{Na}_{2} \mathrm{O}$ and $\mathrm{MgO}$ concentrations of single specimens systematically increase towards the EDJ (Fig. 2) and are well correlated (Fig. 4). This suggests that the element distribution is controlled by a single process in which with advancing apatite crystallization, from the EDJ towards the outside rim, the enamel fluid becomes depleted in $\mathrm{Ba}$ and $\mathrm{Sr}$ as well as $\mathrm{Mg}$ and $\mathrm{Na}$. The epithelial cells control the transport of $\mathrm{Ba}, \mathrm{Sr}$, and $\mathrm{Mg}$ into the crystallization compartment, but there crystallizing apatite incorporates these elements into its lattice. Thus, apatite-fluid partition coefficients $\left(D_{\mathrm{Ap}-\mathrm{Fl}}\right)$ are greater than one. Qualitatively, the relative partitioning behavior can be estimated using the correlation diagrams of these elements (Fig. 4). The regression line of an element pair with similar $D_{\text {Ap-Fl }}$ will pass through the origin of the diagram and a constant element ratio is determined by the slope of the trend. In cases where element pairs have different partition coefficients element ratios are not constant and the regression trend crosses the axes of the element with lower $D_{\mathrm{Ap}-\mathrm{Fl}}$. This analysis suggests that partition coefficients increase in the order of $\mathrm{Sr}<\mathrm{Mg}<\mathrm{Ba}$.

Brügmann et al. (2012) suggested that apatite precipitation occurs in an isolated or semi-isolated chamber and that crystallization follows a Rayleigh fractionation law. At the end of appositional growth, the crystallites of the entire enamel tissue are in equilibrium with the enamel fluid because there should be a fully interconnected fluid network due to the low mineral density in enamel at this time. The highest $\mathrm{Sr}, \mathrm{Ba}$, $\mathrm{MgO}$ and $\mathrm{Na}_{2} \mathrm{O}$ concentrations at the EDJ are used to calculate the element concentrations in the enamel fluid at the beginning and during the course of maturation applying the
Rayleigh fractionation law. The observed and calculated distributions of $\mathrm{Ba}, \mathrm{Sr}, \mathrm{MgO}$ and $\mathrm{Na}_{2} \mathrm{O}$ in enamel are compared in Fig. 4 and Table 2. There is a very good agreement between model and observation assuming apatite-fluid partition coefficients $\left(D_{\mathrm{Ap}-\mathrm{Fl}}\right)$ of $1.25,1.2$ and 1.15 for $\mathrm{Ba}, \mathrm{Mg}$ and $\mathrm{Sr}$, respectively (Table 2). This sequence is consistent with that of the qualitative estimate. In cases where the enamel profile is completely preserved, the calculations imply that 99 to $95 \%$ of crystallization is necessary in order to explain the element variations (Table 2; Fig. 4). This agrees very well with the amount of mineral present in enamel after maturation.

Our estimated partition coefficients for bioapatite and enamel fluid are consistent with results from inorganic precipitation experiments and in vivo studies (Wells et al., 2000; Balter and Lécuyer, 2010) considering the principal uncertainties associated with low temperature experimental results and their application to biological processes and our idealized modeling approach. In reality, enamel formation occurs in an open system where in- and out-fluxes of the elements are controlled by the surrounding epithelium. These fluxes are not known, though, which impedes a detailed quantitative description. The absolute value of the partition coefficients may increase if the elements are continuously added to the tooth forming compartment during maturation. The relative sequence of partition coefficients, nonetheless, should be preserved.

\subsection{Concentration variations on the regional and temporal scale: environmental implications}

At the scale of a specimen, i.e. habitat, the alkaline earth elements covary very well. Thus, element ratios such as $\mathrm{Sr} / \mathrm{Ca}$ and $\mathrm{Ba} / \mathrm{Ca}$ categorize hierarchical structures in a specific food web and information about the trophic, climatic and 


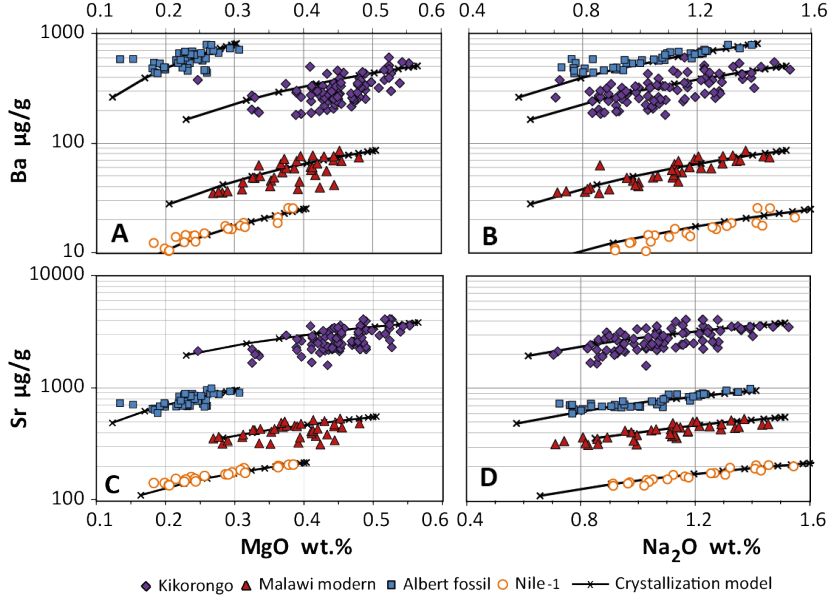

Fig. 4. Variation of $\mathrm{MgO}, \mathrm{Na}_{2} \mathrm{O}, \mathrm{Sr}$ and $\mathrm{Ba}$ in modern and fossil enamel from hippopotamid teeth. Note the large variation of $\mathrm{Ba}$ and $\mathrm{Sr}$ concentrations relative to $\mathrm{MgO}$ and $\mathrm{Na}_{2} \mathrm{O}$. The coherent variation of all elements regardless of age, element concentrations and profile location implies that the concentrations are controlled by a common process. Black lines represent model calculation assuming fractional crystallization of apatite from enamel fluid. For details see Sect. 4.1.2 and Table 2.

geological background of a given environment can be obtained. However, on a regional scale this covariation is obliterated, because there are differences among sedimentary environments, and even systematic changes with geologic time can be observed.

\subsubsection{Trophic level of hippopotamids in different ecosystems}

There is an overall positive correlation between $\mathrm{Sr} / \mathrm{Ca}$ and $\mathrm{Ba} / \mathrm{Ca}$ of bone and tooth tissues (Fig. 5a). Hippopotamids are grazers; however, the variation of $\mathrm{Ba} / \mathrm{Ca}$ and $\mathrm{Sr} / \mathrm{Ca}$ in the studied enamel samples covers the entire herbivore array, including that of browsers, and even extends into the fields defined by plants and carnivores (Fig. 5b). Even so, the slopes of the $\mathrm{Ba} / \mathrm{Ca}$ and $\mathrm{Sr} / \mathrm{Ca}$ variation in different ecosystems are fairly similar. This was recognized by Balter (2004), who summarized the data from several ecosystems and suggested that the slope represents an allometric constant of the biopurification process in mammalian food chains. $\mathrm{Ba} / \mathrm{Ca}$ and $\mathrm{Sr} / \mathrm{Ca}$ in enamel from single hippopotamid specimens follow this trend very well (Fig. 5a). As discussed in the previous paragraph, this trend is controlled by the partitioning behavior of $\mathrm{Ba}$ and $\mathrm{Sr}$ between apatite and enamel fluid. If this suggestion is valid, it is apparent why $\mathrm{Ba} / \mathrm{Ca}$ and $\mathrm{Sr} / \mathrm{Ca}$ in bone and tooth tissues provide the same information regarding the affiliation of mammals to specific trophic levels. Both materials consist of bioapatite which is deposited from fluids with similar major element compositions. Therefore, partition coefficients for trace elements such as $\mathrm{Ba}$ and $\mathrm{Sr}$ should
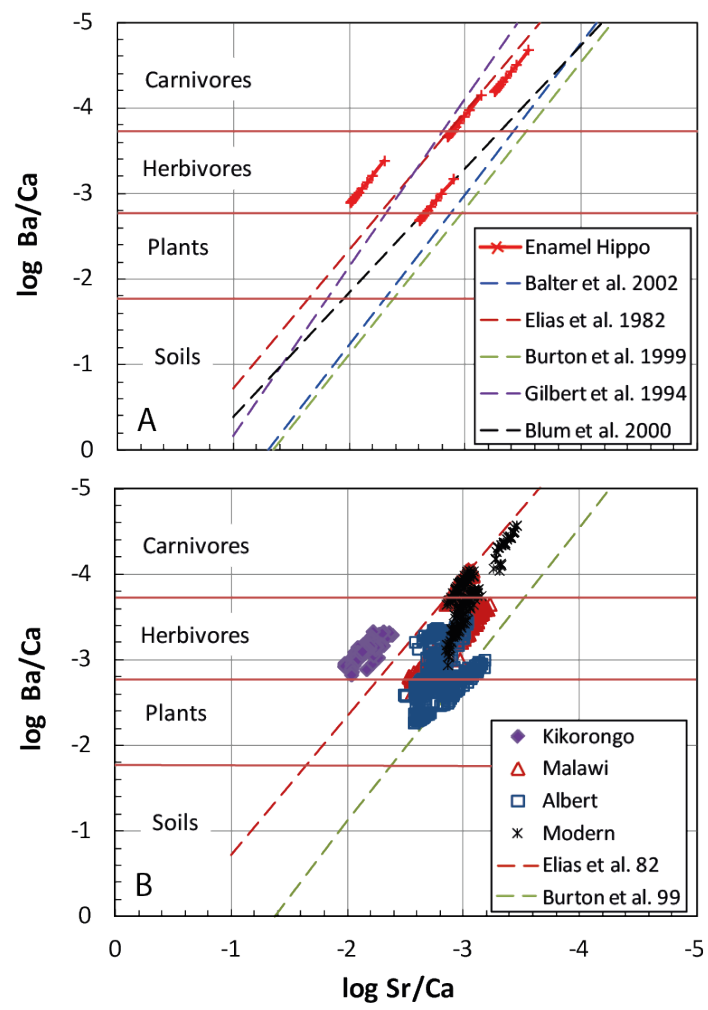

Fig. 5. Trophic levels in different ecosystems as defined by the $\mathrm{Sr} / \mathrm{Ca}$ and $\mathrm{Ba} / \mathrm{Ca}$ variation in bones and teeth. The ranges of $\mathrm{Ba} / \mathrm{Ca}$ defining the trophic levels are from (Balter et al., 2002). (a) Compilation of published $\mathrm{Sr} / \mathrm{Ca}$ and $\mathrm{Ba} / \mathrm{Ca}$ values representing different ecosystems. The dashed lines represent regression lines of data covering several trophic levels in single ecosystems or represent averages summarizing several ecosystems. Red lines with crosses show crystallization models of the variation of $\mathrm{Sr} / \mathrm{Ca}$ and $\mathrm{Ba} / \mathrm{Ca}$ in enamel from hippopotamids of this study as shown in Fig. 4. Note that the slope of the variation of enamel is similar to that observed in ecosystems. Data sources are given in the legend. (b) Variation of $\mathrm{Sr} / \mathrm{Ca}$ and $\mathrm{Ba} / \mathrm{Ca}$ in enamel of hippopotamids teeth analyzed in this study. Enamel displays a large range which extends from the field of herbivore well into the fields of carnivores and plants.

be alike during the formation of these tissues. Barium and $\mathrm{Sr}$ are special in that both elements are not essential nutrients of mammals and it may be that extracellular $\mathrm{Ba}$ and $\mathrm{Sr}$ are not under strict homeostatic control. In addition, $\mathrm{Ba}$ and $\mathrm{Sr}$ are concentrated to $93 \%$ and $99 \%$, respectively, in the skeletal parts of animals (Schroeder et al., 1972; Nielsen, 2004). Thus, the crystallization of bioapatite is the key process controlling the distribution of these elements in the body and this makes $\mathrm{Ba} / \mathrm{Ca}$ and $\mathrm{Sr} / \mathrm{Ca}$ in teeth and bones of mammals to precious monitors of the ingested diet.

However, one should expect that elements having different apatite-fluid partition coefficients define different slopes. Indeed, the variation of $\mathrm{Pb} / \mathrm{Ca}$ and $\mathrm{Ba} / \mathrm{Ca}$ follows a different path with a lower slope (Balter, 2004). For toxic elements, 
such as $\mathrm{Pb}$, or essential elements $(\mathrm{Cu}, \mathrm{Zn})$ the discrimination relative to Ca may be subjected to additional metabolic controls and to significant incorporation in different organs, which also influence the element pathway from ingestion to incorporation into bioapatite. Therefore, different taxa may induce vital effects which significantly overprint the diet signal (Hirao and Patterson, 1974; Balter, 2004).

\subsubsection{Spatial variation of alkaline earth element concentrations: tracers of ecosystems}

In the hippopotamid specimens collected in different geographic regions $\mathrm{Sr}$ and $\mathrm{Ba}$ concentrations vary by up to 2 orders of magnitude (Figs. 4, 6). Among the Nile specimens enamel from the Blue Nile has the highest $\mathrm{Sr}$ concentrations $\left(\sim 447 \mu \mathrm{g} \mathrm{g}^{-1}\right)$. Enamel from Lake Kikorongo has extraordinary high $\mathrm{Sr}$ concentrations $\left(>1500 \mu \mathrm{g} \mathrm{g}^{-1}\right)$ which are much higher than those in specimens from modern and fossil lakes and, in particular, rivers $\left(<1100 \mu \mathrm{g} \mathrm{g}^{-1}\right.$; Fig. 6g). The natural environments of Lake Kikorongo and the Blue Nile are set apart by their association with basaltic volcanic rocks, whereas the remaining tooth specimens are from hippopotamids which lived in waters having ArchaeanProterozoic granite-gneiss terranes in their catchment area. Preliminary $\mathrm{Sr}$ isotopic compositions of the Nile specimens are given in Fig. 6b. Enamel from the Blue Nile has the lowest ${ }^{87} \mathrm{Sr} /{ }^{86} \mathrm{Sr}$ of $0.7056 \pm 0.0001$. This isotope ratio is identical to that of dissolved $\mathrm{Sr}$ in the Blue Nile water and approaches values which are typical for the Ethiopian flood basalts (0.7035-0.7045; (Palmer and Edmond, 1989; Kieffer et al., 2004). Enamel from the basaltic crater of Lake Kikorongo also has relatively unradiogenic ${ }^{87} \mathrm{Sr} /{ }^{86} \mathrm{Sr}(\sim 0.708$; Brügmann et al., 2008). This is within the range observed for the water in the crater lakes of the Katwe-Kikoronga area $\left({ }^{87} \mathrm{Sr} /{ }^{86} \mathrm{Sr}: 0.706-0.717\right.$; Bahati et al., 2005) and is consistent with a habitat dominated by basaltic volcanic rocks. These rock types commonly have higher $\mathrm{Sr}$ contents than typical upper crustal rocks (Kieffer et al., 2004; Rudnick et al., 2003) and this may explain the relatively high $\mathrm{Sr}$ concentrations in enamel from the Blue Nile and Lake Kikorongo.

Enamel of the specimen from the White Nile has among the lowest $\mathrm{Sr}$ content of all specimens and its ${ }^{87} \mathrm{Sr} /{ }^{86} \mathrm{Sr}$ is relatively radiogenic $(0.7182 \pm 0.0004$; Fig. $6 \mathrm{~b})$. This signifies the presence of old continental crust along the watershed of the river because these lithologies have typically radiogenic $\mathrm{Sr}$ isotopic compositions with ${ }^{87} \mathrm{Sr} /{ }^{86} \mathrm{Sr}>0.71$. The outlet lake of the White Nile is Lake Albert which lies within Archaean and Proterozoic crustal rocks and waters and sediments from the Albert and Victoria Nile River have radiogenic ${ }^{87} \mathrm{Sr} /{ }^{86} \mathrm{Sr}$ of 0.7114 to 0.722 (Palmer and Edmond, 1989; Padoan et al., 2011).

The correlation of $\mathrm{Ba}$ with $\mathrm{Sr}$ in the enamel from the Nile River evokes that $\mathrm{Ba}$ concentrations also trace the water provenance (Fig. 6h). The low Ba concentration in enamel from the White Nile, however is unexpected, because
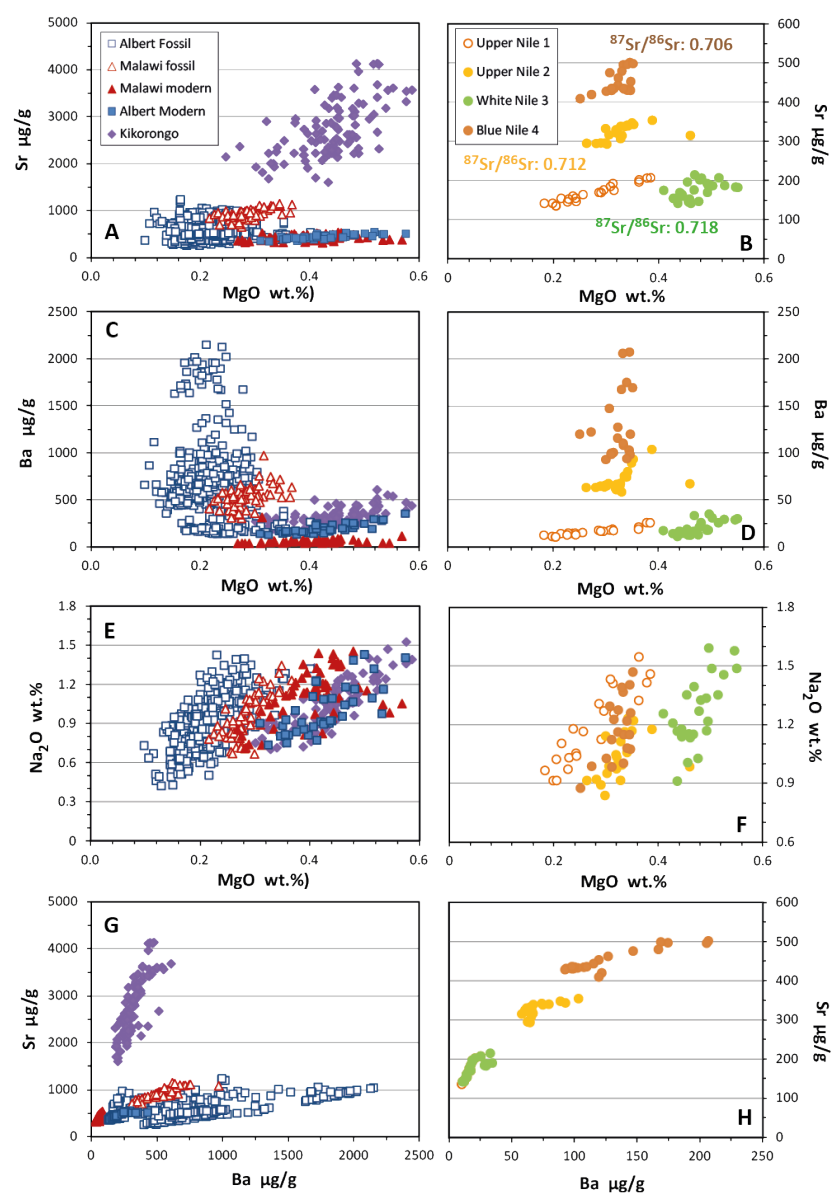

Fig. 6. Variation of $\mathrm{Ba}, \mathrm{Sr}, \mathrm{MgO}$ and $\mathrm{Na}_{2} \mathrm{O}$ in modern and fossil molar enamel from hippopotamids. Data of $\mathrm{MgO}$ and $\mathrm{Na}_{2} \mathrm{O}$ are from (Brügmann et al., 2012). (a, c, e, g) $\mathrm{MgO}-\mathrm{Sr}, \mathrm{MgO}-\mathrm{Ba} \mathrm{MgO}-$ $\mathrm{Na}_{2} \mathrm{O}$ and $\mathrm{Ba}-\mathrm{Sr}$ variation in lacustrine enamel. (b, $\left.\mathbf{d}, \mathbf{f}, \mathbf{h}\right) \mathrm{MgO}-\mathrm{Sr}$, $\mathrm{MgO}-\mathrm{Ba} \mathrm{MgO}-\mathrm{Na}_{2} \mathrm{O}$ and $\mathrm{Ba}-\mathrm{Sr}$ variation in enamel from the Nile River.

Archean upper crustal rocks have typically higher Ba contents than mafic volcanic rocks (Rudnick et al., 2003; Kieffer et al., 2004). Typically, the upper crust has $\mathrm{Ba} / \mathrm{Sr}$ of about 2 whereas basaltic rocks have ratios $<1$. Enamel from the Nile River has low $\mathrm{Ba} / \mathrm{Sr}$ of less than 0.3 (Table 1). This suggests that $\mathrm{Ba}$ in the sedimentary environments along the River Nile is either dominantly of volcanic origin or its availability is controlled by processes overwhelming the input of the source rock. Indeed, there is no systematic relationship between $\mathrm{Sr}$ and $\mathrm{Ba}$ in the lake specimens and even $\mathrm{Ba} / \mathrm{Sr}$ ratios are highly variable ranging from about 0.2 in modern enamel from Lake Malawi to 2 in fossil samples from Lake Albert (Table 1; Figs. 6g, 7). The most plausible explanation is that $\mathrm{Ba}$ is less mobile than $\mathrm{Sr}$ during erosion and weathering of upper continental crust.

A low $\mathrm{Ba} / \mathrm{Sr}(<1)$ is a typical feature in watersheds of several modern rivers including such draining granitic source 
rocks (Dalai et al., 2002) and also East African lakes (Tanganyika, Malawi) have low Ba/Sr (Sako et al., 2007; Branchu et al., 2010). The reduced mobility of Ba relative to $\mathrm{Sr}$ in granite-gneiss watersheds is probably caused by scavenging of Ba by clay minerals and oxy-hydroxides or barite precipitation after $\mathrm{Ba}$ and $\mathrm{Sr}$ became released during the weathering of plagioclase, K-feldspar and mica (Hanor, 2000). In particular, in alkaline and saline environments Ba mobility is reduced compared to low $\mathrm{pH}$ surface and groundwater reservoirs (Hanor, 2000; Witherow and Lyons, 2011).

The $\mathrm{MgO}$ content in enamel is not exclusively controlled by the input from the source rock, but is modified by the local hydrological conditions. $\mathrm{MgO} / \mathrm{Na}_{2} \mathrm{O}$ in enamel from modern Lake Albert is higher than that of modern Lake Malawi (Fig. 6e). This could mirror a difference in the salinity of the lakes because the salinity of Lake Albert is five times higher than that of Lake Malawi (Talling and Talling, 1965). The higher $\mathrm{MgO} / \mathrm{Na}_{2} \mathrm{O}$ in enamel of modern Lake Albert compared to that in fossil Lake Albert probably also reflects the evolution of the lake water chemistry. This is indicated by the evaporation trend in Lake Albert since at least about 6.5 $\mathrm{Ma}$ as suggested by increasing $\delta^{18} \mathrm{O}$ of hippopotamid enamel during that time (Brachert et al., 2010).

\subsubsection{Temporal variation of alkaline earth element concentrations in enamel: tracers of environmental change}

Another conspicuous feature is the highly variable Ba concentration in enamel from different stratigraphic units of the Lake Albert region. Whereas Sr concentrations in these specimens vary on average by about a factor of less than 3 , Ba concentration vary by one order of magnitude causing a large variation of the $\mathrm{Ba} / \mathrm{Sr}$ (Table 1; Figs. 6a, c, g, 7a). There is a systematic decrease of Ba concentration as well as $\mathrm{Ba} / \mathrm{Ca}$ (not shown) or $\mathrm{Ba} / \mathrm{Sr}$ with geological age: Miocene enamel has higher $\mathrm{Ba} / \mathrm{Sr}$ than Pliocene, Pleistocene as well as Holocene and modern enamel, respectively (Fig. 7a). In contrast, $\mathrm{Sr} / \mathrm{Ca}$ values are rather constant during this time span (Fig. 7b).

This decrease of $\mathrm{Ba} / \mathrm{Sr}$ with time could be caused by postmortem alteration processes or by changing diet compositions reflecting vital effects or hydrological conditions. It may seem possible that the $\mathrm{Ba}$ increase with geological age is due to secondary addition during diagenetic alteration. No other major or trace element, however, shows such a relationship with geological age. It is also not seen for those elements which are most severely affected by post-mortem alteration, such as $\mathrm{FeO}$ or $\mathrm{F}$ (Brügmann et al., 2012). In addition, as discussed in Sects. 4.1.1 and 4.1.2, modern and fossil specimens show the same Ba distribution, which even correlates well with $\mathrm{Mg}, \mathrm{Na}$ or $\mathrm{Sr}$ within individual enamel samples. This represents a primary feature, which has been established during amelogenesis. Secondary overprint, therefore, is an unlikely process explaining the temporal Ba variation.

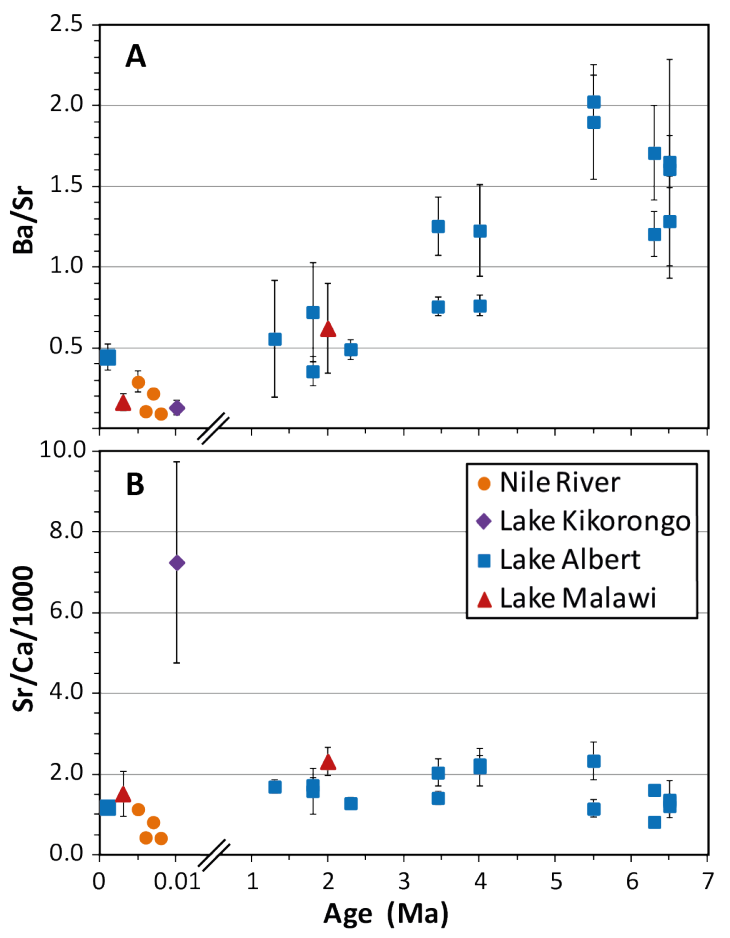

Fig. 7. Temporal variation of $\mathrm{Ba} / \mathrm{Sr}$ and $\mathrm{Sr} / \mathrm{Ca}$ in modern and fossil molar enamel from hippopotamids. Note the break along the axis of the abscissas; age of modern specimens is not to scale. (a) $\mathrm{Ba} / \mathrm{Sr}$ in enamel versus geological age. Notice the systematic decrease of $\mathrm{Ba} / \mathrm{Sr}$ with age which suggests limited Ba mobility relative to $\mathrm{Sr}$ in the Pleistocene ( $<2.5 \mathrm{Ma}$ ) compared to the Pliocene and Miocene. (b) $\mathrm{Sr} / \mathrm{Ca}$ in enamel versus geological age indicating no significant fractionation between $\mathrm{Sr}$ and $\mathrm{Ca}$ with time.

The alternative explanation is that the composition of the hippopotamid diet has changed, either because of a change of dietary preferences or a change of the diets chemical composition. Indeed, our set of specimens includes different taxa; the modern teeth belong to the large-size species Hippopotamus amphibius, but the fossil teeth include both large and small size animals, which may belong to different taxa. Hippopotamids, however, are regarded as opportunistic feeders. Even if these taxa had different dietary preferences, however, an influence of vital effects on the $\mathrm{Ba} / \mathrm{Ca}$ or $\mathrm{Ba} / \mathrm{Sr}$ with time is unlikely, because the samples do not reflect a systematic chronological distribution of the taxa populations.

Hence, the variation of these ratios with geological age indicates a systematic change of the diet composition, including that of drinking water. This can be attributed to a decrease of the availability of Ba relative to $\mathrm{Sr}$ for plants and ultimately to hippopotamids, i.e. it is controlled by environmental change. The western branch of the East African Rift system experienced a regional or mesoscale climate change during the Miocene-Pleistocene, which is supported by sedimentary and paleobotanical observations and stable isotope compositions of hippopotamid enamel. From 7.5 to $2.5 \mathrm{Ma}$, 
a large paleolake (Palaeolake Obweruka) covered the present regions of Lake Albert, Lake Edward, and Lake George (Pickford et al., 1993; Van Damme and Pickford, 2003). The average $\delta^{18} \mathrm{O}$ values of the surface water of the paleolake in the Albertine Rift, as calculated from the $\delta^{18} \mathrm{O}$ values of hippopotamid enamel, systemically increase from $-8 \%$ to $+2 \%$ at 6.5 to $2 \mathrm{Ma}$ (Brachert et al., 2010). This variation implies increasing evaporation of the water reservoir in the Albertine Rift and aridification with time. Ferruginized plant remains in sediments of the palaeolake indicate the dominance of $\mathrm{C}_{3}$ vegetation typical for tropical forests between 7 and $4 \mathrm{Ma}$ (Dechamps and Ergo, 1994; Pailler et al., 2000). $\delta^{13} \mathrm{C}$ values of hippopotamid enamel vary between -12 and $-9 \%$ o during this period also indicating a $\mathrm{C}_{3}$ diet (Brachert et al., 2010). During such tropical-humid climate conditions, intensive erosion and weathering of the upper crustal watershed of Lake Albert may have effectively transported $\mathrm{Sr}$ and $\mathrm{Ba}$ towards Paleolake Obweruka minimizing the fractionation of these elements. At around 3 to $2 \mathrm{Ma}$, Paleolake Obweruka disintegrated into a lake configuration similar to that of today (Pickford et al., 1993). At the same time, arid steppe and open savannah type vegetation became dominant (Dechamps and Ergo, 1994; Pailler et al., 2000). This is also supported by $\delta^{13} \mathrm{C}$ data in hippopotamid enamel indicating a propagation of $\mathrm{C}_{4}$ grasses during that time (Brachert et al., 2010). Under arid conditions chemical weathering is less intense which should cause a decreasing $\mathrm{Ba}$ and $\mathrm{Sr}$ flux towards Lake Albert. Rather constant $\mathrm{Sr} / \mathrm{Ca}$, however, do not show this effect (Fig. 7b). Thus, the low Ba/Sr suggests lower mobility of Ba relative to $\mathrm{Sr}$ under these climate conditions which is related to the preferred adsorption of $\mathrm{Ba}$ on clay minerals and oxy-hydroxides. In addition, the formation of alkaline, even saline lake and soil waters is a typical feature of arid regions. There is no indication for a saline Lake Albert during the Pliocene-Pleistocene, however, aridification could increase the alkalinity of weathering solutions, which would inhibit the mobility of Ba due to precipitation of barite.

Stable isotope data of mammalian fossils and palaeosol carbonates from various areas of the East African Rift system have been interpreted to indicate an enduring regional aridification during the Neogene (Trauth et al., 2007). However, as Brachert et al. (2010) noticed the studied archives are preferentially in depositional environments of the graben floor and thus may dominantly monitor the mesoclimate of the rift valleys. Thus, an alternative interpretation, which is in agreement with systematics in element concentrations and ratios (e.g., $\mathrm{Ba} / \mathrm{Sr}$ ) as well as with stable and radiogenic isotope proxies, is that the temporal variation rather reflects the response to a tectonic reorganization of the Albertine Rift system (graben subsidence/shoulder uplift) during the Neogene (Brachert et al., 2010).

\section{Synthesis and perspective}

Bioapatite is in mammals a large buffer for alkaline earth elements, because for example in humans $99 \%$ of $\mathrm{Ca}$ and $\mathrm{Sr}, 93 \%$ of $\mathrm{Ba}$, and $50 \%$ of $\mathrm{Mg}$ are stored in this mineral (Schroeder et al., 1972; Wester, 1987; Kunsch and Kunsch, 2006). These elements transport chemical information from the external environment into bone and tooth tissues, which contain, therefore, records of historical and ancient environmental change. The archive investigated here is premolar and molar hippopotamid tissue from lacustrine and fluvial environments (6.5 Ma to recent) of Eastern Africa. The variation of the concentrations of $\mathrm{CaO}(1 \sigma \sim 1 \%), \mathrm{MgO}(1 \sigma \sim 38 \%)$, as well as $\mathrm{Ba}$ and $\mathrm{Sr}(1 \sigma \sim 85 \%$ and $91 \%$, respectively) in enamel is controlled in vivo, by the function of these elements in the animal, and externally, by the distribution of these elements in the habitats. The very low variation of $\mathrm{Ca}$ in enamel is expected because of its fixed concentration in extracellular fluids as well the tight stoichiometric control during apatite deposition. Such an overwhelming physiological control precludes the use of $\mathrm{Ca}$ concentrations as an environmental proxy. Magnesium is also an important essential nutritional element and animals living in fresh water ecosystems have to pump this element into their cells - in contrast to cells of marine organisms, which have to reject $\mathrm{Mg}$ - in order to maintain homeostatic conditions. This in turn means that the Mg budget in terrestrial organisms could in addition underlie an extrinsic control, which is most probably reflected in the higher concentration variation compared to that of $\mathrm{Ca}$. This weaker physiological control allows the distinction of saline and freshwater habitats or provenance signals using ratios such $\mathrm{MgO} / \mathrm{CaO}$ or $\mathrm{MgO} / \mathrm{Na}_{2} \mathrm{O}$.

In contrast, large variations of $\mathrm{Ba}$ and $\mathrm{Sr}$ concentrations in tooth tissues are possible due to their non-essential nature in mammals. The variations are caused by secondary postmortem effects, crystallization processes during amelogenesis, and compositional differences of the ingested nutrition. Secondary alteration severely modified $\mathrm{Ba}$ and $\mathrm{Sr}$ distributions in dentin and cement but for enamel it has no significant influence on the overall population statistics.

On the scale of a hippopotamid tooth there are linear correlations between $\mathrm{MgO}$, $\mathrm{Sr}$ and $\mathrm{Ba}$ concentrations in enamel. These trends suggest that one common process controls the behavior of the alkaline earth elements during amelogenesis. This process can be quantitatively described by a Rayleigh crystallization model which presumes that after appositional growth the element distributions are controlled by apatite crystallization during the maturation stage of amelogenesis. Model consistent apatite-fluid Nernst partition coefficients for $\mathrm{Sr}, \mathrm{Mg}$ and $\mathrm{Ba}$ would be 1.15, 1.2, and 1.25, respectively. Enamel formation, however, occurs in a semi-permeable open system, where element transport is physiologically mediated. These fluxes as well as the influence of the protein matrix on apatite precipitation are not well-known. Therefore, Rayleigh crystallization has to be 
regarded as a simplified conceptual model describing the chemical variation in enamel.

On a regional scale, $\mathrm{Ba}$ and $\mathrm{Sr}$ variations in enamel can be related to variable diet compositions in different habitats which in turn reflect different water provenance and hydrochemical conditions. The large variations of $\mathrm{Ba} / \mathrm{Ca}(2.4$ $\log$ units), $\mathrm{Sr} / \mathrm{Ca}$ (1.5 log units) and $\mathrm{Ba} / \mathrm{Sr}$ (1.3 log units) in enamel imply that the plant signal entering the food chain is highly heterogeneous with regard to these elements. Enamel of each hippopotamid, however, shows a specific chemical signal which fingerprints the environmental setting of the animal's small territory. Thus, it is possible to estimate the $\mathrm{Ba} / \mathrm{Sr}$ of the food ingested by hippopotamids by adjusting the observed ratio with that of the apatite-fluid partition coefficients of $\mathrm{Ba}$ and $\mathrm{Sr}$. The catchment areas of lakes and rivers impose a dominant signature onto the hippopotamid habitats. Within fluvial and lacustrine environments, enamel from hippopotamids which were dependent on water masses draining basaltic source rocks have higher $\mathrm{Sr}$ concentrations and lower $\mathrm{Ba} / \mathrm{Sr}$, than enamel from animals living in water reservoirs draining Archean crustal rocks. This provenance influence is supported by the Sr isotopic composition of enamel.

The temporal decrease of $\mathrm{Ba} / \mathrm{Sr}$ in enamel from the Lake Albert Rift may indicate a hydrochemical adjustment in the watershed of the Albertine Rift due to a change from humid to arid climate during the Neogene. The Miocene record of the rift is characterized by a tropical climate. Intense weathering in the catchment area of the lake may have mobilized $\mathrm{Ba}$ and $\mathrm{Sr}$ to similar degrees. Thus, $\mathrm{Ba} / \mathrm{Sr}$ values of 1.5 to 2, which are typical for Archean upper crust, are preserved in the sediment trap of Lake Albert. From ca. 6.5 to $2 \mathrm{Ma}$ the region underwent pronounced aridification. During this time, $\mathrm{Sr} / \mathrm{Ca}$ or $\mathrm{Mg} / \mathrm{Ca}$ in enamel remained constant, indicating no significant fractionation of these elements at the watershed of the rift lake. $\mathrm{Ba} / \mathrm{Sr}$ in enamel, though, decreased to values as low as 0.5 suggesting a restricted mobility of $\mathrm{Ba}$. This decrease is interpreted to be the effect of aridification aggravating the preferential scavenging of Ba to clay and $\mathrm{Fe}$ oxide-hydroxide minerals or causing the formation of more alkaline, possibly sulfate-bearing weathering and soil solutions. In this case, river and ground water fluxes from the watershed to Lake Albert would transport a low $\mathrm{Ba} / \mathrm{Sr}$ signal to the hippopotamid habitat.

Alkaline earth elements are also important constituents of biological and inorganic carbonates and provide proxies tracing environmental information, such as salinity or temperature changes. The partition behavior of $\mathrm{Ba}$ and $\mathrm{Sr}$ towards carbonates and apatite is very similar which should facilitate the cross calibration of these archives. This would integrate a highly persuasive amount of chemical information on a variety of diverse sedimentary environments. Eventually, a comprehensive fundament builds up which permits the prediction of the influence of climate change on regional environments - one of today's foremost scientific problems.

\section{Supplementary material related to this article is available online at: http://www.biogeosciences.net/9/ 4803/2012/bg-9-4803-2012-supplement.pdf.}

Acknowledgements. The authors acknowledge the thoughtful comments of the anonymous reviewers. We thank our Ugandan research partners (Makerere University, Kampala) for their support as well as A. Schumann (Kampala) for his help with logistics. K.-H. Becker, M. Maus and A. Budsky (University of Mainz) and M. Biegler (Max Planck Insitute for Chemistry, Mainz) prepared thin sections and mini core samples. This study was funded by the German Research Foundation (DFG, Research Unit RIFTLINK, project $\mathrm{C} 1$ ).

Edited by: W. Kiessling

\section{References}

Bahati, G., Pang, Z., Ármannsson, H., Isabirye, E. M., and Kato, V.: Hydrology and reservoir characteristics of three geothermal systems in western Uganda, Geothermics, 34, 568-591, 2005.

Balter, V.: Allometric constraints on $\mathrm{Sr} / \mathrm{Ca}$ and $\mathrm{Ba} / \mathrm{Ca}$ partitioning in terrestrial mammalian trophic chains, Oecologia, 139, 83-88, doi:10.1007/s00442-003-1476-0, 2004.

Balter, V. and Lécuyer, C.: Determination of $\mathrm{Sr}$ and $\mathrm{Ba}$ partition coefficients between apatite and water from $5^{\circ} \mathrm{C}$ to $60^{\circ} \mathrm{C}$ : A potential new thermometer for aquatic paleoenvironments, Geochim. Cosmochim. Acta, 68, 423-432, 2004.

Balter, V. and Lécuyer, C.: Determination of Sr and Ba partition coefficients between apatite from fish (sparus aurata) and seawater: The influence of temperature, Geochim. Cosmochim. Acta, 74, 3449-3458, 2010.

Balter, V., Bocherens, H., Person, A., Labourdette, N., Renard, M., and Vandermeersch, B.: Ecological and physiological variability of $\mathrm{Sr} / \mathrm{Ca}$ and $\mathrm{Ba} / \mathrm{Ca}$ in mammals of west european Mid-Würmian food webs, Palaeogeogr. Palaeoclimatol., 186, 127-143, 2002.

Betzler, C. and Ring, U.: Sedimentology of the Malawi rift: Facies and stratigraphy of the Chiwondo Beds, northern Malawi, Journal of Human Evolution, 28, 23-35, 1995.

Beuning, K. R. M., Talbot, M. R., and Kelts, K.: A revised 30,000year paleoclimatic and paleohydrologic history of Lake Albert, East Africa, Palaeogeogr. Palaeoclimatol., 136, 259-279, 1997.

Blum, J. D., Taliaferro, E. H., Weisse, M. T., and Holmes, R. T.: Changes in $\mathrm{Sr} / \mathrm{Ca}, \mathrm{Ba} / \mathrm{Ca}$ and ${ }^{87} \mathrm{Sr} /{ }^{86} \mathrm{Sr}$ ratios between trophic levels in two forest ecosystems in the northeastern U.S.A., Biogeochemistry, 49, 87-101, doi:10.1023/a:1006390707989, 2000.

Bobe, R., Alemseged, Z., Behrensmeyer, A. K., Sandrock, O., Kullmer, O., Schrenk, F., Juwayeyi, Y. M., and Bromage, T. G.: Fauna, taphonomy, and ecology of the Plio-Pleistocene Chiwondo Beds, northern Malawi, in: Hominin environments in the East African Pliocene: An assessment of the faunal evidence, Vertebrate paleobiology and paleoanthropology, Springer Netherlands, 315-332, 2007.

Boisserie, J.-R. and Merceron, G.: Correlating the success of hippopotaminae with the $\mathrm{C}_{4}$ grass expansion in Africa: Relationship 
and diet of early Pliocene hippopotamids from Langebaanweg, South Africa, Palaeogeogr. Palaeoclimatol., 308, 350-361, 2011. Boisserie, J.-R., Zazzo, A., Merceron, G., Blondel, C., Vignaud, P., Likius, A., Mackaye, H. T., and Brunet, M.: Diets of modern and Late Miocene hippopotamids: Evidence from carbon isotope composition and micro-wear of tooth enamel, Palaeogeogr. Palaeoclimatol., 221, 153-174, 2005.

Boskey, A. L.: Mineralization of bones and teeth, Elements, 3, 385391, doi:10.2113/gselements.3.6.385, 2007.

Brachert, T., Brügmann, G., Mertz, D., Kullmer, O., Schrenk, F., Jacob, D., Ssemmanda, I., and Taubald, H.: Stable isotope variation in tooth enamel from Neogene hippopotamids: Monitor of meso and global climate and rift dynamics on the Albertine Rift, Uganda, Int. J. Earth Sci., 99, 1663-1675, doi:10.1007/s00531010-0518-1, 2010.

Branchu, P., Bergonzini, L., Ambrosi, J.-P., Cardinal, D., Delalande, M., Pons-Branchu, E., and Benedetti, M.: Hydrochemistry (major and trace elements) of Lake Malawi (Nyasa), Tanzanian Northern Basin: local versus global considerations, Hydrol. Earth Syst. Sci. Discuss., 7, 4371-4409, doi:10.5194/hessd7-4371-2010, 2010.

Brügmann, G. E., Brachert, T. C., Ssemmanda, I., and Mertz, D. F.: Chemical and isotope compositions of neogene Hippopotamidae teeth from Lake Albert (Uganda): Implications for environmental change, Eos trans. Agu, 89(53), Fall Meet. Suppl., Abstract pp11d-01, 2008.

Brügmann, G., Krause, J., Brachert, T. C., Kullmer, O., Schrenk, F., Ssemmanda, I., and Mertz, D. F.: Chemical composition of modern and fossil Hippopotamid teeth and implications for paleoenvironmental reconstructions and enamel formation - Part 1: Major and minor element variation, Biogeosciences, 9, 119-139, doi:10.5194/bg-9-119-2012, 2012.

Burton, J. H., Price, T. D., and Middleton, W. D.: Correlation of bone $\mathrm{Ba} / \mathrm{Ca}$ and $\mathrm{Sr} / \mathrm{Ca}$ due to biological purification of calcium, Journal of Archaeological Science, 26, 609-616, 1999.

Cameron, E. M., Hall, G. E. M., Veizer, J., and Krouse, H. R.: Isotopic and elemental hydrogeochemistry of a major river system: Fraser River, British Columbia, Canada, Chemical Geology, 122, 149-169, 1995.

Cerling, T. E., Harris, J. M., Hart, J. A., Kaleme, P., Klingel, H., Leakey, M. G., Levin, N. E., Lewison, R. L., and Passey, B. H.: Stable isotope ecology of the common hippopotamus, J. Zool., 276, 204-212, doi:10.1111/j.1469-7998.2008.00450.x, 2008.

Chansa, W., Milanzi, J., and Sichone, P.: Influence of river geomorphologic features on hippopotamus density distribution along the Luangwa River, Zambia, African Journal of Ecology, 49, 221226, doi:10.1111/j.1365-2028.2010.01252.x, 2011a.

Chansa, W., Senzota, R., Chabwela, H., and Nyirenda, V.: The influence of grass biomass production on hippopotamus population density distribution along the Luangwa River in Zambia, Journal of Ecology and the Natural Environment, 3, 186-194, $2011 \mathrm{~b}$.

Dalai, T. K., Krishnaswami, S., and Sarin, M. M.: Barium in the Yamuna River system in the Himalaya: Sources, fluxes, and its behavior during weathering and transport, Geochem. Geophys. Geosyst., 3, 1076, doi:10.1029/2002gc000381, 2002.

Dalai, T. K., Krishnaswami, S., and Kumar, A.: $\mathrm{Sr}$ and ${ }^{87} \mathrm{Sr} /{ }^{86} \mathrm{Sr}$ in the Yamuna River system in the Himalaya: Sources, fluxes, and controls on $\mathrm{Sr}$ isotope composition, Geochim. Cosmochim. Acta, 67, 2931-2948, 2003.
Dechamps, R. and Ergo, A.: Palaeovegetation (fossil plants) of the Albertine Rift Valley, in: Geology and palaeobiology of the Albertine Rift Valley, Uganda - Zaire, vol. Ii: Palaeobiology, edited by: Sénut, B., and Pickford, M., Cifeg publication occasionelle, Centre International pour la Formation et les Echanges Geologiques, Orléans Cedex 2, 29-45, 1994.

Domingo, L., Grimes, S. T., Soler-Gijón, R., and López-Martínez, N.: Analysis of the geochemical variability in lepisosteid scales from the Fontllonga-3 site (Early Danian, Tremp Formation, South Central Pyrenees, Spain): Implications for palaeoenvironmental studies, Palaeogeogr. Palaeoclimatol., 274, 204-214, 2009.

Dupre, B., Gaillardet, J., Rousseau, D., and Allegre, C. J.: Major and trace elements of river-borne material: The Congo Basin, Geochim. Cosmochim. Acta, 60, 1301-1321, 1996.

Elias, R. W., Hirao, Y., and Patterson, C. C.: The circumvention of the natural biopurification of calcium along nutrient pathways by atmospheric inputs of industrial lead, Geochim. Cosmochim. Acta, 46, 2561-2580, 1982.

Elsdon, T. S. and Gillanders, B. M.: Temporal variability in strontium, calcium, barium, and manganese in estuaries: Implications for reconstructing environmental histories of fish from chemicals in calcified structures, Estuar. Coast. Shelf Sci., 66, 147-156, 2006.

Eltringham, S. K. and Barrett, P.: The hippos, A\&C Black, 2010.

Gaillardet, J., Dupré, B., Allègre, C. J., and Négrel, P.: Chemical and physical denudation in the Amazon River Basin, Chemical Geology, 142, 141-173, 1997.

Garzanti, E., Andò, S., France-Lanord, C., Vezzoli, G., Censi, P., Galy, V., and Najman, Y.: Mineralogical and chemical variability of fluvial sediments: 1. Bedload sand (Ganga-Brahmaputra, Bangladesh), Earth Planet. Sc. Lett., 299, 368-381, 2010.

Garzanti, E., Andò, S., France-Lanord, C., Censi, P., Vignola, P., Galy, V., and Lupker, M.: Mineralogical and chemical variability of fluvial sediments 2. Suspended-load silt (Ganga-Brahmaputra, Bangladesh), Earth Planet. Sc. Lett., 302, 107-120, 2011.

Hanor, J. S.: Barite-celestine geochemistry and environments of formation, Reviews in Mineralogy and Geochemistry, 40, 193-275, doi:10.2138/rmg.2000.40.4, 2000.

Harris, J. M., Cerling, T. E., Leakey, M. G., and Passey, B. H.: Stable isotope ecology of fossil hippopotamids from the Lake Turkana Basin in East Africa, J. Zool., 275, 323-331, doi:10.1111/j.14697998.2008.00444.x, 2008.

Hirao, Y. and Patterson, C. C.: Lead aerosol pollution in the High Sierra overrides natural mechanisms which exclude lead from a food chain, Science, 184, 989-992, doi:10.1126/science.184.4140.989, 1974.

Hoppe, K. A., Koch, P. L., and Furutani, T. T.: Assessing the preservation of biogenic strontium in fossil bones and tooth enamel, International Journal of Osteoarchaeology, 13, 20-28, 2003.

Jochum, K. P., Stoll, B., Herwig, K., and Willbold, M.: Improvement of in situ $\mathrm{Pb}$ isotope analysis by LA-ICP-MS using a $193 \mathrm{~nm}$ Nd:Yag laser, Journal of Analytical Atomic Spectrometry, 21, 666-675, 2006.

Jochum, K. P., Stoll, B., Herwig, K., and Willbold, M.: Validation of LA-ICP-MS trace element analysis of geological glasses using a new solid-state $193 \mathrm{~nm} \mathrm{Nd:Yag} \mathrm{laser} \mathrm{and} \mathrm{matrix-matched}$ calibration, Journal of Analytical Atomic Spectrometry, 22, 112 $121,2007$. 
Kieffer, B., Arndt, N., Lapierre, H., Bastien, F., Bosch, D., Pecher, A., Yirgu, G., Ayalew, D., Weis, D., Jerram, D. A., Keller, F., and Meugniot, C.: Flood and shield basalts from Ethiopia: Magmas from the African superswell, Journal of Petrology, 45, 793-834, doi:10.1093/petrology/egg112, 2004.

Kohn, M. J.: Models of diffusion-limited uptake of trace elements in fossils and rates of fossilization, Geochim. Cosmochim. Acta, 72, 3758-3770, 2008.

Koch, P. L., Halliday, A. N., Walter, L. M., Stearley, R. F., Huston, T. J., and Smith, G. R.: Sr isotopic composition of hydroxyapatite from recent and fossil salmon: The record of lifetime migration and diagenesis, Earth Planet. Sc. Lett., 108, 277-287, 1992.

Kronberg, B. I., Nesbitt, H. W., and Fyfe, W. S.: Mobilities of alkalis, alkaline earths and halogens during weathering, Chem. Geol., 60, 41-49, 1987.

Kunsch, K. and Kunsch, S.: Der Mensch in Zahlen, 3 ed., Spektrum Akademischer Verlag, Heidelberg, Berlin, 420 pp., 2006.

Land, M., Ingri, J., Andersson, P. S., and Öhlander, B.: Ba/Sr, Ca/Sr and ${ }^{87} \mathrm{Sr} /{ }^{86} \mathrm{Sr}$ ratios in soil water and groundwater: Implications for relative contributions to stream water discharge, Appl. Geochem., 15, 311-325, 2000.

Lear, C. H., Elderfield, H., and Wilson, P. A.: Cenozoic deep-sea temperatures and global ice volumes from $\mathrm{Mg} / \mathrm{Ca}$ in benthic foraminiferal calcite, Science, 287, 269-272, doi:10.1126/science.287.5451.269, 2000.

Lee-Thorp, J. and Sponheimer, M.: Three case studies used to reassess the reliability of fossil bone and enamel isotope signals for paleodietary studies, Journal of Anthropological Archaeology, 22, 208-216, 2003.

Margolis, H. C., Beniash, E., and Fowler, C. E.: Role of macromolecular assembly of enamel matrix proteins in enamel formation, Journal of Dental Research, 85, 775-793, doi:10.1177/154405910608500902, 2006.

McCulloch, M. T., Gagan, M. K., Mortimer, G. E., Chivas, A. R., and Isdale, P. J.: A high-resolution $\mathrm{Sr} / \mathrm{Ca}$ and $\delta^{18} \mathrm{O}$ coral record from the Great Barrier Reef, Australia, and the 1982-1983 El Nino, Geochim. Cosmochim. Acta, 58, 2747-2754, 1994.

McCulloch, M., Cappo, M., Aumend, J., and Müller, W.: Tracing the life history of individual barramundi using laser ablation MC-ICP-MS Sr-isotopic and Sr/Ba ratios in otoliths, Marine and Freshwater Research, 56, 637-644, doi:10.1071/MF04184, 2005.

Millard, A. R. and Hedges, R. E. M.: A diffusion-adsorption model of uranium uptake by archaeological bone, Geochim. Cosmochim. Acta, 60, 2139-2152, 1996.

Milton, D., Halliday, I., Sellin, M., Marsh, R., Staunton-Smith, J., and Woodhead, J.: The effect of habitat and environmental history on otolith chemistry of barramundi lates calcarifer in estuarine populations of a regulated tropical river, Estuar. Coast. Shelf Sci., 78, 301-315, 2008.

Nesbitt, H. W., Markovics, G., and price, R. C.: Chemical processes affecting alkalis and alkaline earths during continental weathering, Geochim. Cosmochim. Acta, 44, 1659-1666, 1980.

Nielsen, S. P.: The biological role of strontium, Bone, 35, 583-588, 2004.

Padoan, M., Garzanti, E., Harlavan, Y., and Villa, I. M.: Tracing Nile sediment sources by $\mathrm{Sr}$ and $\mathrm{Nd}$ isotope signatures (Uganda, Ethiopia, Sudan), Geochim. Cosmochim. Acta, 75, 3627-3644, 2011.
Pailler, D., Flicoteaux, R., Ambrosi, J.-P., and Médus, J.: Les bois Mio-Pliocènes de Nkondo (Llac Albert, Ouganda); composition minéralogique et mode de formation, Comptes Rendus de l'Academie des Sciences - Series IIA - Earth and Planetary Science, 331, 279-286, 2000.

Palmer, M. R. and Edmond, J. M.: The strontium isotope budget of the modern ocean, Earth Planet. Sc. Lett., 92, 11-26, 1989.

Pasteris, J. D., Wopenka, B., and Valsami-Jones, E.: Bone and tooth mineralization: Why apatite?, Elements, 4, 97-104, doi:10.2113/gselements.4.2.97, 2008.

Phillis, C. C., Ostrach, D. J., Ingram, B. L., and Weber, P. K.: Evaluating otolith $\mathrm{Sr} / \mathrm{Ca}$ as a tool for reconstructing estuarine habitat use, Canadian Journal of Fisheries and Aquatic Sciences, 68, 360-373, doi:10.1139/f10-152, 2011.

Pickford, M., Senut, B., and Hadoto, D.: Geology and palaeontology of the Albertine Rift Valley, Uganda-Zaire, Publication Occasionelle, Centre International pour la Formation et les Echanges Geologiques, Orléans Cedex 2, 1-190, 1993.

Riebe, C. S., Kirchner, J. W., and Finkel, R. C.: Erosional and climatic effects on long-term chemical weathering rates in granitic landscapes spanning diverse climate regimes, Earth Planet. Sc. Lett., 224, 547-562, 2004.

Ring, U. and Betzler, C.: Geology of the Malawi Rift: Kinematic and tectonosedimentary background to the Chiwondo Beds, Northern Malawi, Journal of Human Evolution, 28, 7-21, 1995.

Robinson, C., Kirkham, J., Brookes, S. J., Bonass, W. A., and Shore, R. C.: The chemistry of enamel development, Int. J. Dev. Biol. , 39, 145-152, 1995.

Rudnick, R. L., Gao, S., Editors-in-Chief: Heinrich, D. H., and Karl, K. T.: 3.01 - composition of the continental crust, in: Treatise on geochemistry, Pergamon, Oxford, 1-64, 2003.

Sako, A., Sarkar, D., Datta, R., and Hannigan, R.: Chapter 7 geochemical cycling of trace and rare earth elements in Lake Tanganyika and its major tributaries, in: Developments in environmental sciences, Elsevier, 135-171, 2007.

Sandrock, O., Dauphin, Y., Kullmer, O., Abel, R., Schrenk, F., and Denys, C.: Malema: Preliminary taphonomic analysis of an African hominid locality, Comptes Rendus de l'Academie des Sciences - Series IIA - Earth and Planetary Science, 328, 133139, 1999.

Schroeder, H. A., Tipton, I. H., and Nason, A. P.: Trace metals in man: Strontium and barium, Journal of Chronic Diseases, 25, 491-517, 1972.

Senut, B. and Pickford, M.: Geology and palaeobiology of the Albertine Rift Valley, Uganda-Zaire. Volume ii: Palaeobiology, in: Publication occasionnelle - centre international pour la formation et les echanges geologiques CIFEG Orléans, 1-423, 1994.

Shiller, A. M.: Dissolved trace elements in the Mississippi River: Seasonal, interannual, and decadal variability, Geochim. Cosmochim. Acta, 61, 4321-4330, 1997.

Sillen, A.: Elemental and isotopic analyses of mammalian fauna from Southern Africa and their implications for paleodietary research, American Journal of Physical Anthropology, 76, 49-60, 1988.

Sillen, A. and Lee-Thorp, J. A.: Trace element and isotopic aspects of predator-prey relationships in terrestrial foodwebs, Palaeogeogr. Palaeoclimatol., 107, 243-255, 1994.

Simmer, J. P., Papagerakis, P., Smith, C. E., Fisher, D. C., Rountrey, A. N., Zheng, L., and Hu, J. C.-C.: Regulation of den- 
tal enamel shape and hardness, J. Den. Res., 89, 1024-1038, doi: $10.1177 / 0022034510375829,2010$.

Smith, C. E.: Cellular and chemical events during enamel maturation, Critical Reviews in Oral Biology \& Medicine, 9, 128-161, doi:10.1177/10454411980090020101, 1998.

Smith, C. E. and Nanci, A.: Overview of morphological changes in enamel organ cells associated with major events in amelogenesis, Int. J. Dev. Biol., 39, 153-161, 1995.

Sponheimer, M. and Lee-Thorp, J. A.: Enamel diagenesis at South African australopith sites: Implications for paleoecological reconstruction with trace elements, Geochim. Cosmochim. Acta, 70, 1644-1654, 2006.

Talling, J. F. and Talling, I. B.: The chemical composition of African lake waters, Internationale Revue der gesamten Hydrobiologie und Hydrographie, 50, 421-463, doi:10.1002/iroh.19650500307, 1965.

Trauth, M. H., Maslin, M. A., Deino, A. L., Strecker, M. R., Bergner, A. G. N., and Dühnforth, M.: High- and low-latitude forcing of Plio-Pleistocene East African climate and human evolution, Journal of Human Evolution, 53, 475-486, 2007.

Trueman, C. N. G., Behrensmeyer, A. K., Tuross, N., and Weiner, S.: Mineralogical and compositional changes in bones exposed on soil surfaces in Amboseli National Park, Kenya: Diagenetic mechanisms and the role of sediment pore fluids, Journal of Archaeological Science, 31, 721-739, 2004.

Tütken, T., Vennemann, T. W., and Pfretzschner, H. U.: Early diagenesis of bone and tooth apatite in fluvial and marine settings: Constraints from combined oxygen isotope, nitrogen and REE analysis, Palaeogeogr. Palaeoclimatol., 266, 254-268, 2008.
Van Damme, D. and Pickford, M.: The Late Cenozoic thiaridae (mollusca, gastropoda, cerithioidea) of the Albertine Rift Valley (Uganda-Congo) and their bearing on the origin and evolution of the Tanganyikan thalassoid malacofauna, Hydrobiologia, 498, 1-83, doi:10.1023/a:1026298512117, 2003.

Wells, B. K., Bath, G. E., Thorrold, S. R., and Jones, C. M.: Incorporation of strontium, cadmium, and barium in juvenile spot (leiostomus xanthurus) scales reflects water chemistry, Canadian Journal of Fisheries and Aquatic Sciences, 57, 2122-2129, doi:10.1139/f00-178, 2000.

Wells, B. K., Rieman, B. E., Clayton, J. L., Horan, D. L., and Jones, C. M.: Relationships between water, otolith, and scale chemistries of westslope cutthroat trout from the Coeur d'Alene River, Idaho: The potential application of hard-part chemistry to describe movements in freshwater, Transactions of the American Fisheries Society, 132, 409-424, doi:10.1577/15488659(2003)132;0409:rbwoas;2.0.co;2, 2003.

Wester, P.: Magnesium, The American Journal of Clinical Nutrition, 45, 1305-1312, 1987.

White, A. F., Blum, A. E., Bullen, T. D., Vivit, D. V., Schulz, M., and Fitzpatrick, J.: The effect of temperature on experimental and natural chemical weathering rates of granitoid rocks, Geochim. Cosmochim. Acta, 63, 3277-3291, 1999.

Witherow, R. and Lyons, W. B.: The fate of minor alkali elements in the chemical evolution of salt lakes, Saline Systems, 7, 1-17, 2011. 